\title{
LA CAPELLA DE MÚSICA DE LA SEU DE BARCELONA EN EL SEGLE XVIII (1756-1765)
}

Josep PAVIA I Simó

\begin{abstract}
This study is a continuation of my published work concerning the history of the Music Chapel in the Barcelona Cathedral during all of the XVII and the first half of the XVIII centuries, and it is faithful to the methodology I have hitherto employed. You will, therefore, come across many of the musicians I have referred to in my previous articles, as well as some new names, plus novel and similar circumstances that enlivened the musical life of the said Cathedral and which were scrutinized by its Chapter. Some points pertaining to certain persons and matters have been left unanswered in this present study, but which I hope to address at a later stage.
\end{abstract}

\section{Resum}

Aquest treball, mantè la mateixa línia metodòlogica, emprada en els meus treballs publicats sobre la Capella de Música de la Catedral de Barcelona, durant tot el segle XVII i la primera meitat del s. XVIII, dels quals n'és continuació. Hi trobareu, doncs, molts músics, dels quals ja se n'ha parlat en els precedents treballs, en trobareu de nous i també circunstàncies, unes noves i d'altres semblants que animaren la vida musical de l'esmentada Catedral i n'eren la preocupació del Capítol. Alguns punts, tocants a certes persones o matèries, queden sense resolució final, al present treball. Espero poder-les oferir, en altra col·laboració posterior.

\section{La Capella de Música.}

\section{Generalitats}

Constitucions, redreçament del Cor, canvi d'horari i Consueta. En començar la dècada 1756-1765, encara no s'havien codificat totes aquestes qüestions i el Capítol n'estava preocupat i interessat. El tema devia presentar certes dificultats, sobre tot en la pràctica de les Ordinacions o Constitucions antigues, com es reconeix en algun document que al-ludeix a "la inobservancia de Aquellas".

Efectivament, l'acta capitular del 17 de maig de 1756, recull la moció presentada pel canonge Quintana, amb què feia present la necessitat que hi havia de dur a terme els projectes de: renovació de les "Constitucions de la Igl.a", el redrés del Cor, mutació de hores de Cor i de Vespres, a l'estiu ("per la inobservancia de aquellas", enteneu les Constitucions actuals) i formació de la Consueta per al règim del Capítol. El Capítol resolgué, per a l'afer Constitucions, confirmar la comissió que s'havia fet al succentor Vilar i al canonge Tagell, el 7 de juliol de 1755. Tocant a la mutació d'entrada a les hores, recordava Quintana que, el 4 d'agost de 1753, s'havia decidit no tractar-la fora dels Capítols 
Pasquals, circumstància en què aleshores es trobaven i que el Capítol trobà molt oportuna. En aquesta sessió, confirmaren igualment la comissió feta, als Srs. canonges Quintana, Dalmases, Bessa i Puigjaner. Confirmació que també es donà a la comissió feta a Quintana, a Rius i a Tagell, el primer de juliol de 1754, per al redreçament del Cor. I, per a la formació d'una nova Consueta, o reformar l'anterior, comissionaren el Secretari. L'acta conclou recomanant a tots els membres d'aquestes comissions, que procuressin fer relació de la pròpia comissió, abans de concloure els Capítols Pasquals, per tal que el Capítol pogués deliberar el més convenientment possible. ${ }^{1}$

Sorprenentment, l'acta capitular del divendres 9 de maig de l'any 1760, diu que els Srs. comissionats, Vilar, succentor i Tagell, canonge, no havien presentat la recopilació de les Constitucions, tot i que feia temps que els havia estat comesa, com tampoc el reglament del Cor, del qual feia anys que en tenien la comissió. El Capítol els renovà el mateix encàrrec i manà al Secretari que recopilés les resolucions preses, relativament al reglament del Cor $^{2}$.

L'acta capitular de 1'11 de juliol del 1760 permet entreveure que la dificultat era de procediment, ja que el canonge Tagell es negava a participar en la comissió, si, després, el Capítol ho havia de tenir, com s'acostuma a dir, “com paper mullat" i, en conseqüència, proposà que s'anomenessin Promotors "als q.e se subjecte lo q.e acordaran, i q.e aprobat per estos dega absolutam.t observarho lo Cap.l”. Aquest, però, resolgué que s'afegís a la comissió el Penitencier i que, si el Sr. Tagell no volia continuar en la comissió, que la deixés. Tanmateix, la darrera paraula, a l'hora d'aprobar, afegir o rectificar la proposta dels comissionats, corresponia, per dret i costum, al Capítol ${ }^{3}$. Sembla, pels documents que segueixen, que Tagell continuà en la comissió.

Finalment, l'acció dels comissionats fou més ràpida i, així, el 21 dels susdits mes i any, fou presentat un esborrany, o paper al Sr. Secretari, del qual paper es diu que "lo S.or Can.e Tagell ha fet pnt, que havia posat en mà del Secretari un paper q.e era com un Preludi â la Colleccio de las Constitucions, i manifestacio de la idea, q.e se pretént pendrer en aquella Obra, i q.e se llegiría, si aparegués al M. I. Cap.l.", el qual resolgué que, abans el llegissin el succentor Vilar i el canonge Pou i, després, ja el presentarien al Capítol ${ }^{4}$.

Sembla que el succentor Vilar i el canonge Pou foren expedits en la seva missió i dos dies després, això és, el 23 de juliol del 1760, l'acta capitular informa que el Secretari havia llegit un paper titulat: Apparatus ad Constitutionum compilationem, ejusque divisio, treballat pel canonge Tagell, amb què donava diferents notícies, pel que feia a l'origen i a les Administracions de la Catedral de Barcelona i explicava el mètode que pensava observar en la susdita compilació. Un cop llegit el paper, es prengué l'acord de donar les gràcies a dit Tagell pel treball que se n'havia près, així com també li aprobaren el mètode proposat per dur a terme la tal compilació, tot esperant que els senyors comissionats es dedicarien a fons en la realització d'aquesta obra de tant d'interès per a la Catedral ${ }^{5}$.

1. SIV. 22 , f. 138

2. SIV. 23, f. 188

3. SIV. 23, f. 197.

4. SIV. 23, f. 199 .

5. SIV. 23, f. 199v. 
Un any després, aproximadament, això és, el 17 de juliol de 1761, el secretari capitular féu present que l'any anterior li havien fet comissió, juntament amb el succentor Vilar, pel que feia a les Ordinacions del Cor i distribució del temps que s'havia d'emprar en el rés de les Hores, però que, havent mort el susdit Vilar, demanava al Capítol que nomenés altre capitular per a la comissió i foren nomenats els canonges Mateu, Roig i el secretari. ${ }^{6}$ Aquests comissionats, això és, Mateu, Roig i també Pou, qui devia ser el secretari, el dia 24 següent, manifestaren al Capítol, que ells s'havien llegit les Constitucions i només hi objectaven que "com son tan difusas, apenas haurá, qui se impose en ellas..." Per això creien oportú fer-ne un extracte o resum, per capítols separats, en cada ú dels quals constés tot allò que corresponia a genuflexions, salutacions, serveis "y demes". Així es facilitaria el domini de les corresponents cerimònies. El Capítol autoritzà l'extracte.?

Constitucions noves sobre els Músics. Els canonges Mateu i Orteu feren relació, en la sessió capitular del 13 de maig de 1763, que, en compliment de la Comissió que tenien sobre els Músics, havien reunit diferents vegades els Músics de la Capella, primerament els vells, i després els joves, i que els havien llegit les Noves Constitucions, dient-los que en donessin lliurement el seu parer, per tal de portar-ho dits Comissionats a capítol i que tots les havien trobat bé. I, puig que, a més a més, en tot eren conformes a l'estil i pràctica del Capítol i cercaven en tot la unió en la Capella, consideraven que es podien aprobar i manar que es complissin. També explicaren, com en l'elaboració d'aquestes Constitucions sobre els músics, havien esbrinat en què consistia la Concordia ${ }^{8}$, Conveni, ô Unio de la Capella de V. S. amb la de Santa Maria del Mar i havien trobat diferents papers, en els Manuals de l'Escrivania, on constava que l'any 1649 es féu una Concòrdia entre el Mestre, Capítol i les Obres de Santa Maria del Mar, Santa Maria del Pi, Sant Just i Sant Miquel, sobre poder anar aqueixes Capelles de música a cantar fora de las pròpies esglésies (la Catedral en tenia el dret en exclusiva, des de temps immemorial) i fou concordat, que hi podrien anar, mitjançant el pagament de tres lliures cada Obra parroquial, el dia de Corpus, al M. I. Capítol, exceptuant-ne les esglésies de Santa Caterina, Betlem, Diputació i Llotja. També hi constava que aquestes 12 lliures foren consignades al Mestre de Capella, "en 1660, y tants" i es diu que, aquest, les cobrà tan sols uns anys ${ }^{9}$. Els comissionats, doncs, opinavan i consellaven, que caldria, en primer lloc, manar al Mestre de Capella que anul-lés i revoqués la tal unió, o conveni entre la Capella de V. S. y la de Santa Maria del Mar, novament fet; en segon lloc, fer cumplir en tots els seus termes i conseqüències, la Concòrdia antiga de 1649. El Capítol, doncs, aprobà l'anul-lació del nou conveni amb Santa Maria del Mar i deixà a l'estudi i decisió dels Comissionats la qüestió de la Concòrdia antiga i altres problemes d'intercanvi de cantaires, sobre tot de la Capella de Santa Maria del Mar ${ }^{10}$.

6. SIV. 24 , f. $38 \mathrm{v}$.

7. SIV. 24 , f. 40.

8. Aquesta Concòrdia i més detalls són tractats per mi, a la meva tesi doctoral, "La música a la Catedral de Barcelona, durant el segle XVII”, Fundació Salvador Vives i Casajuana, Barcelona, 1986, pp. 35ss.

9. Un document que parla d'aquesta qüestió, és de l'11 de febrer del $1658 \mathrm{i}$ diu, literalment copiat: "Se ha resolt en orde ha alguna cobransa que ha de fer lo mestre de cant de las Parrochias per raho de hanar ha cantar los mestres de ditas parrochias que sels fassan apochas com sis cobrava tot per enter y que sels fassa cortesia de dos añades y si sen pot traurer maior partit que lo Pabordre Mans hi fasse las diligensias possibles". Res. Cap. 1650-60, sense foliar.

10. SIV. 24, f. $147 \mathrm{v}$. 
L'acta capitular del divendres 5 d'agost del 1763, diu que encara no s'havia dut a terme la qüestió de les Constitucions del cor, tot i que feia molt de temps que el Capítol tenia feta comissió a alguns capitulars, com es palesa de la intervenció del Sr. Antonino de Sentmanat, el qual féu present que "fins ara no la han executada, y q.e hi ha molta necessitat de ellas" i demanava que s'hi donés alguna providència ${ }^{11}$.

Un altre apartat de la mateixa acta del 5 d'agost de $1763^{12}$, es fa ressò de les queixes del canonge Roldós, Protector de la Capella, tocant a un Músic, que en lloc de recórrer a ell, ho feia a un altre Capitular, donant com excusa, que el Protector "se'ls treia de davant". I que, en aquest supòsit, posava el càrrec a disposició del Capítol, altrament no tindria cura de son ofici. El Capítol resolgué que continués en l'ofici de Protector de la Capella, i que el canonge Mateu reprengués seriosament el susdit Músic, per parlar d'aquella manera contra el Sr. Protector. I s'aprofità l'ocasió per urgir “q.e las Constitucions de la Capella se evacuen, quant antes se firmen, y se posen en execucio".

Finalment, l'acta del 4 de maig de 1764 diu que, aqueix dia, foren llegides les "Constitucions de la p.nt Iglesia", pel notari del Capítol. ${ }^{13}$

Música a dos Coros. El 28 de febrer de 1765, el Capítol concedí permís, a petició d'un devot, de celebrar un ofici amb música a dos cors, a Sant Oleguer, deixant-ho, però, a la discreció del canonge Nadal. ${ }^{14}$ Per "ofici", col-loquialment, hom entén la "Missa", però en aquell temps no hi havia misses vespertines. No sabem, doncs, quina mena d" "ofici" devia ser.

Música patètica. Si es té present que patètic/-a vol dir: emocionant, commovedor o que desperta sentiments forts, s'entendrà fàcilment què pretenia el devot que volia fundar una Causa pia amb "música patètica", destinada a "quant se posa, y se trau lo Santissim Sagrament del Monument per las horas de las Vetllas, ô guarda en los intermedis, y los quarts de pausa"15, com consta a l'acta capitular del 7 de març de 1763. Com sempre, el Capítol va delegar en els Arxivers i el canonge Antonino Sentmenat, en aquest cas, la tasca d'examinar les condicions de la fundació, perquè després l'informessin. ${ }^{16}$

11. SIV. 24 f. 163v: N(ota) M(arginal): Proposicio, q.e fa lo S.or D.r Antonino Sentmanát, sobre lo q.e fa molt temps, q.e lo Cap.l té feta Comisió â alguns S.ors Capitulars per las Constitucions de Chor, y que fins ara no la han executada, y q.e hi ha molta necesitat de ellas, per lo q.e demana, se done alguna providencia. Text. Die Veneris 5 Augusti 1763 hora 9a Matutina. D.n Antoníno Sentmenat ha fet p.nt, q.e fa molt temps, q.e lo Cap.1 té Comisió feta â alguns S.ors Capitulars per las Constitucions de Chor, q.e feren dits Sors. relació â V. S. q.e las havían examinadas, be, q.e per sa mes facil observancia, ô inteligencia fore molt convenient fer una extraccio, ô resumen de ellas, q.e â dits S.ors se encarregá la execucio, q.e fa molt temps de aixo, pero fins ara no han posat en execucio, q.e V. S. la desigualtat en lo Chor, q.e tots volen ser Dueños, q.e segons, qui es President, se va molt precipitats, q.e altras vegadas molt solemnes sens ningun orde; q.e los Ento-/nadors se governan, com volen, y altras cosas, q.e cada hu de V. S. no ignora; per lo q.e fa p.nt, pera q.e V.S. se servesca donár alguna providencia.

Rt. Que los dits S.ors Comisaris cuiden de evacuar las Constitucions de Chor, y q.e miren la Consueta del Arxiu, q.e té lo S.or Capiscol, y q.e se pose en execucio quant antes".

12. SIV. 24 , f. $163 \mathrm{v}$.

13. SIV. 24, f. $200 \mathrm{v}$.

14. SIV. 24, f. 244v.

15. Francesc Valls, en el seu Mapa Armónico Práctico, parla, al menys dues vegades, de la "Musica Pathetica" i de les qualitats que ha de tenir. L'una (pg 313 de l'edició, no del ms.), parlant dels Trocados, diu “que este genero de Musica es mas adaptable en composiciones Patheticas, que no en assumptos alegres" i l'altra (pg. 425): "El Organista... en los Graduales, Ofertorios, y elevacion de el Ssmo Sacramento podrá tocar de Phantasia lo q.e quisiere; mas al alzar procure, que la Musica sea Pathetica, pausada, y devota; porque no distrayga al celebrante, ni á los que assisten á tan alto sacrificio",

16. SIV. 24, f. 136. 
Deu dies després, això és, a la sessió capitular del 17 del mateix mes i any, el canonge Semenat (sic) i els Arxivers, van plantejar la qüestió de la fundació de música per al Monument que volia fer un devot, i les condicions de la dotació, perquè tingués garantia de duració. Després d'haver-les considerat, preguntaren al mestre de Capella quant importaria per hora la susdita fundació i aquest digué que volia una "lliura per cada hora: que la Musica será tan patetica, com quant se posa, y se trau lo Santissim Sagrament del Monument; y q.e la Musica se posará detrás de la Mesa del Monument, y los apar q.e V. S. podría admetrer esta fundacio, encara, q.e est any se comense pagánt, y se han tingut presents varios punts". Fou resolt, doncs, que s'acceptés la fundació, deixant-ne l'execució al canonge Sentmenat i als Arxivers. Ometo l'explicació del contingut del document, en la part que fa referència a la manera de dotar aquesta fundació, amb la qual es pretenia assegurar econòmicament les penalitats dels músics que hi intervindrien. ${ }^{17}$

Música nova. Com es llegeix a la nota marginal de l'acta capitular de 12 de març de 1764, va sorprendre "la novedat de la Musica nova de la Ciutat". I és que una "Musica nova de la Ciutat" -pot ser avui en diríem "xaranga nova"- que devia desconéixer les normes, va crear un problema, jo diria de protocol, a la processó de Sta. Eulàlia, ja que els "Timbals" es posaren després de la Creu -i sembla que això era la "novedat"-. De moment es va tolerar, però, després de la processó, el canonge Quintana, ho va tractar amb "D.n Ver-/nardino Padellás Regidor de particulár havía anat encontrarlo pera veurer de compondrerse" i, a més, "havía sempre respost, q.e lo Cap.l disposaría". D’altra banda, es considerà també que s'apropava la festa de Sta. Madrona i valia la pena prevenir-se, per evitar tota mena de disturbi. A tal fi, crearen una Comissió, formada pels canonges Quintana i Alòs, aquest, substitut del Succentor, "pera q.e compongan com judíquen mes convenient". ${ }^{18}$

Redreçament (del Cor: hores). Relacionada encara amb el redreçament del Cor, és l'acta que ara comentaré. És del dia 4 de juliol de l'any 1760 i en ella, el canonge Quintana feia present que normalment no es trobaven beneficiats que prenguessin capes per cantar els versos de sexta, per la senzilla raó que s'absentaven del Cor per anar a funerals, i suplicava, que el Capítol prengués alguna determinació, a fi de posar remei a tal situació i es va confiar als senyors Comissionats anomenats per a la inspecció de Ordinacions de Cor, que discorreguessin, pel que feia a la solució ${ }^{19}$.

En la mateixa sessió capitular del 4 de juliol de 1760, el mateix canonge Quintana manifestà que alguns es queixaven d'excessiva precipitació en les hores, al Cor i d'altres de massa lentitud. Demanava, doncs, que es posés remei a aquests defectes. El Capítol resolgué, que Vilar i Tagell, Comissionats per a la qüestió de les Constitucions, reflexionessin sobre aquesta matèria i que el més aviat possible, proposessin les providències que es podrien prendrer "en cosa de tanta importància" ${ }^{20}$

Reprehensió. El dilluns 12 de juliol de 1756, el canonge Nadal, Vicari General, féu present, en sessió capitular, que havia donat una forta reprensió a quatre oficials de la Capella de música, obeint una orde rebuda del Capítol, en el capítol anterior, puix s'entenia que aquests músics volien manar despòticament en ella, tot acusant d'això mateix al Mestre, el qual va donar la part de la Capella a

17. SIV. 24 , f. $138 \mathrm{v}$

18. SIV. 24, f. 196.

19. SIV. 23, f. 195.

20. SIV. 23, f. 195. 
“N”, en contra de l'opinió del Capítol, segons ells tenien entés i que el Mestre els havia dit que ell actuava per orde del Protector, en nom del propi Capítol. El Capítol resolgué donar les gràcies al canonge Nadal i encarregà a Manuel Joven, que era el canonge Protector, quan això va succeir i a l'actual, Antonino Sentmenat, perquè n'informessin. ${ }^{21}$ Consultant la sessió capitular "anterior", de la qual s'ha fet esment, sembla que "N" oculta el nom de "Fc. Casamor", de qui es parlarà més endavant $\mathrm{i}$ es comprobarà que tot va succeir per un descuit del Mestre, en no informar de l'absència justificada d'aquest músic, per malaltia de la seva mare.

Conflictes amb parròquies. Preheminència. La Catedral havia gaudit des de temps immemorial, del privilegi de sortir a cantar la seva Capella de Música, a totes i qualsevol església de Ciutat, mentre que les altres Capelles, si ho volien fer, n-havien d'obtenir prèviament l'autorització, o bé del Capítol o del Mestre.

A l'afer dels problemes entre les parròquies i la Catedral, pel que fa a la preheminència, li vaig dedicar un apartat a la meva tesi doctoral $i$, posteriorment, referències en altres publicacions. Hi publico el text de la Concòrdia, signada el 19 de febrer de l'any 1649 (pg. 35) i el d'un projecte d'unió i agermanament entre la Capella de la Catedral i la del Palau, sense data, preparat segurament pels del Palau (pg. 40), als quals es fa referència en alguna acta posterior. Una nota marginal d'aquest darrer diu: "Papeles que corrieron para el ajuste antes del pleito", això que permet situar el document a finals de gener de 1689, en què el Capítol decideix renunciar a la causa de cant que s'aportava a la Cúria Romana. Al final de l'acta Capitular, hom llegeix: "que al mateix temps escrigan al Sr. Don Dalmau Copons, en Madrid, pera que vege si se trobaria disposició pera tractar de algun ajust ab lo Sr. Marqués de los Vélez", postillla que podria haver donat lloc a l'esmentat document. ${ }^{22}$

El fet de la preheminència de la Capella de Música de la Catedral, per sobre de les altres Capelles, tanmateix, havia estat sempre discutit i contravingut, fins a arribar a entablar un plet, la Catedral contra les parròquies, l'últim terç del segle XVII.

D'acord amb els documents que exposaré tot seguit, hom dedueix que la qüestió de la preheminència de la Catedral es mantenia encara, la segona meitat del segle XVIII. Efectivament, l'acta capitular del 28 d'agost de 1756, es fa ressò de l'incident ocorregut a Santa Maria del Mar, en ocasió d'una sepultura. Era costum que un escolà de la Catedral donés tres cops amb l'anella de la porta $\mathrm{i}$ així ho féu, l'escolà de torn, però no sortí ningú de Santa Maria. En canvi, en tornar de la sepultura, ja no els deixaren acostar i dos escolans de Santa Maria agrediren al de la Seu. Li donaren cops al cap, li feren sang a la mà i li prengueren el salpasser que, després, recuperà. L'acta afegeix: "se coneixia claramént estavan previnguts per est efecte. Es resolgué que els Comissionats per a la Causa de Preheminències donessin tots els passos necessaris, perquè aquest excés fos castigat. ${ }^{23}$

Altra ocasió de discutir-se la preheminència s'esdevingué en ocasió del trasllat del Santíssim Sacrament a l'església nova de Sant Agustí, ocorreguda el 27 de març de 1758. En efecte, el Vicari General i canonge Nadal, convocà capítol a l'hora de lletanies del 26 de març, per comunicar que el

21. SIV. 22, f, 150 .

22. Pavia Simó, J., La música a la Catedral de Barcelona durant el segle XVII. Fundació Salvador Vives i Casajuana, Barcelona, 1986.

23. SIV. 22, f. 162 .

76

(c) Consejo Superior de Investigaciones Científicas Licencia Creative Commons 3.0 España (by-nc)
Anuario Musical, 60 (2005)

http://anuariomusical.revistas.csic.es 
Sr. Bisbe assistiria de pontifical, el dia següent, a la processó de la Translació del Santíssim Sagrament a l'església nova de St. Agustí i esperava que membres del Capítol l'assistirien en aqueixa funció. En conseqüència, Nadal demanà els ornaments i l'assistència d'oficials per a la funció del dimarts, a Sant Agustí. Però el Mestre de Capella recordà que era costum del Capítol de no assistir a funcions, si no era amb la pròpia Capella de Música i que, fins aleshores, a ell no li havien dit res, els de St. Agustí, ni per assistir la Capella a la Processó, ni a la festa del dimarts. I demanava al Capítol que hi prengués la resolució que cregués millor. I el Capítol resolgué que, només s'hi aniria, si actuava la Capella de la Catedral. Sortosament, hi ha dades per assegurar que no hi anà la Capella de la Seu, sinó la del Palau i que s'hi interpretà un "Sacro Músico Drama, y Epinicio", de Josep Duran, Mestre de la Capella del Palau. ${ }^{24}$

Els canonges Mateu i també Orteu, feren relació, el 3 de març de 1763, en virtut de la Comissió que tenien, del resultat de llur investigació sobre la Concòrdia entre la Capella de Música de la Seu i les altres Capelles. Que amb ella pretenien acabar " las varias disputas, q.e se havían suscitat entre las quatre Parroquias S.ta María, N.ra S.ora del Pi \&” i que, mitjançant la Concòrdia s'obligaven les susdites Capelles a donar alguna compensació al Mestre de Capella de la Seu, reservant-se aqueix, però, algunes esglésies. I que després s'havien fet unes Constitucions per a la Capella "q.e son molt utils, las quals se podran llegír, y aprobadas / per V. S. donar orde al Mestre se cumplissen, y al mateix temps se podrá llegír lo paper, q.e ha donat lo Mestre. El Capítol resolgué "deixarho tot enterament â la direccio, y prudencia dels dits S.ors D.n Jph. Matheu, y D.n Fran.co Orteu". ${ }^{25}$

Altre incident entre els escolans de Santa Maria i els de la Seu, en ocasió d'un enterrament i de les mateixes característiques que l'ocorregut uns anys abans, el qual s'ha comentat més amunt, es recull a l'acta capitular del dia 27 de juliol de 1764. El Capítol demanà als Comissionats per a les coses de Preeminències, que prenguessin immediates i serioses providències per a la deguda satisfacció d'aital agravi, insistint-los, al mateix temps perquè, en els altres assumptes de Preeminències donessin els passos concernents per a son efecte. ${ }^{26}$

El 30 de juliol de 1764, els Comissionats per a les coses de Preeminències, feren relació al Capítol de la informació que havien donat al Sr. Bisbe, de l'incident amb els escolans de Santa Maria, tres dies abans, això és, el 27 de juliol pròxim passat. I també, d'altre atemptat semblant ocorregut, aquell mateix dia 30, al matí, a la parròquia de Sant Jaume, amb l'agravant que el dia abans, un dels vicaris de Sant Jaume havia dit als escolans, o monjo de la Seu, "de q.e se guardessen de picar a la Porta", de la qual amenaça hi havia testimonis de la pròpia parròquia i, segons el canonge Joven, hi havia la certesa de trobar altres testimonis de major excepció. El Capítol resolgué prendre immediatament aquests informes dels testimonis. ${ }^{27}$

Encara relacionades amb la preeminència de la Catedral són les dues actes capitulars següents. Ambdues fan referència a la mateixa qüestió. El 10 d'abril de 1765, després de completes, el canon-

24 SIV. 23, f. 135v. I: Pavia Simó, J., La música en Cataluña en el siglo XVIII. Francesc Valls (1671ca.-1747), CSIC, Institució "Milà i Fontanals", Barcelona, 1997, pg. 53, nº 1243.

25. SIV. 24 , f. $135 \mathrm{v}$.

26. SIV. 24, f. $214 \mathrm{v}$.

27. SIV. 24, f. $214 \mathrm{v}$. 
ge Joan Alòs, Protector de la Capella de Música, comunicà que el Mestre de Capella li havia dit que tenia notícia certa que, a Santa Caterina, en ocasió del novenari a St. Vicens, s'havien ajustat amb la Capella de Santa Maria, ignorant la de la Catedral i, per tractar-se d'una novetat que anava en contra dels drets de la Seu, ho denunciava, per tal que s'albirés què s'havia de fer. El Capítol resolgué que el propi canonge Alòs, s'entrevistés amb el prior de Santa Caterina, per esbrinar-ho i posar el remei adequat. ${ }^{28}$ La resposta del canonge Alòs arribà el 12 dels mateixos mes i any. Digué que, després d'haver mantingut diferents converses amb el prior de Santa Caterina, aquest li havia dit que es tractava d'una festa d'uns devots i que no li constava que els havia d'obligar a contractar la Capella de la Catedral, a la qual festa i funcions, d'altra banda, hi assistia la susdita Capella de Santa Maria, per un preu inferior al de la Catedral. I que, no obstant això, en totes les funcions del convent i en les demés que ell tingués notícia, continuaria actuant la de la Catedral. El Capítol donà les gràcies al canonge Alòs i manà als de la Comissió de Preeminències que prenguessin nota de "lo porte y modo dels de S.ta Maria"29.

Infermeria. El canonge Albert Ibarra, Protector de la Capella de Música, va manifestar, en la sessió capitular del 2 de desembre de 1757, que els membres de la susdita Capella li havien exposat que desitjarien que s'erigís -com s'havia fet a Santa Maria del Mar- una Infermeria, per a llur atenció, en cas de malaltia i que per aquest efecte i a fi d'assegurar-ne la pervivència de l'entitat, s'escriguessin unes Constitucions que, amb l'autoritat del Capítol tindrien més segura observància, les quals Ordinacions (sic) se han minutat, se han presentat, y llegít". I afegir que, en virtut d'aquests desigs dels músics, els havia reunit i que tots, no sols estigueren d'acord, sinó que ho signaren. Que considerava molt positiu aquest projecte, el qual seria molt útil per als músics i per a la Catedral, la qual estaria exempta dels seus recursos, encara que els havia tingut sempre que un músic estava malalt o moria. I finalment, que, a més a més de l'aprobació, els obsequiés amb alguna quantitat de diner, com a fons per a iniciar aquesta obra. El Capítol felicità el Sr. Ibarra i creà una Comissió formada pels canonges Mateu, Roig i el propi Ibarra, perquè estudiessin les Ordinacions presentades i sobre la utilitat i posada en marxa de la Infermeria. ${ }^{30}$

28. SIV. 24, f. 246.

29. SIV. 24, f. 246.

30. SIV. 23 , f. $64 \mathrm{v}$.:

"1757"; "12"; "09"; "SIV"; "Arxiucatedral"; "Barcelona"; "Ms"; "426"; "1754-1758"; "Bca"; "Infermeria dels Músics “; "Ordinacions"; "N. M.: [Ordinacions per la Infermeria dels Musichs -v. SIV. 23, f. 65v-]. Text: [Die Veneris 9 decemb.s 1757 hora $\mathrm{x}^{\mathrm{a}}$ matutina]. "Projecte de la Infermeria, y Germandad se deu fer entre los Individuos que vull son, y seràn en avant en la Capella de Musica de la S.ta Yglesia Cathedral per son alivio en casos de malaltia, y sufragi en sa Mort, baix la Protecció del Molt Il.te Capitol, y inspecció del S.or Canonge Protector, â que tingan la millor, y mes exacta observancia los Caapitols seguents.

Primo: Tot, y qualsevol Individuo que en avant entrará en la Capella, so es tindrà part en ella, deurà indispensablement pagar deu Lliuras per la Infermeria, y los actualment admesos deurán solament pagar sinch Lliuras, y los ultims en cas de voler ser admesos.

$2^{\circ}$ : Que no podenlas pagar ab una vegada, se detindráa lo Procurador de la Capella de la part dels tals dos sous per Lliura, fins haver plenament satisfetas las mencionadas sinch, ó deu Lliuras.

$3^{\circ}$ : Deurá cada Individuo pagar per la Infermeria quatre sous quiscum Mes, los que se retindráa lo Procurador de las Mesadas quant se fassa lo pagament y disposará en la Caxa que per est fi hi haurá.

$4^{\circ}$ : Lo producto, ó resultant de las faltas que qualsevol Individuo faráa en las funcions de la Capella sensa excepció de algun, deurá aplicarse â la Infermeria, y disposarse en la mencionada Caxa, com tambe tot lo que no podrá arribar â repartirse dels ploms de qualsevol festa que sia, ó be de Albats entre los que si encontraran.

78

(c) Consejo Superior de Investigaciones Científicas Licencia Creative Commons 3.0 España (by-nc)
Anuario Musical, 60 (2005)

http://anuariomusical.revistas.csic.es 
La Comissió per a la Infermeria es posà immediatament en marxa i una setmana després, això és, el 9 del mateix desembre de 1757, ja presentaren i llegiren les Ordinacions per a la Infermeria de la Capella dels Músics i demanaren al Capítol si, per ajuda de costa, podria donar alguna almoina, per a iniciar aquesta obra i, a més, que es posés un decret i aprobació del Capítol, per a fer més estable l'observància d'aitals Ordinacions. El Capítol, no sols aprobà i confirmà les Ordinacions, sinó que també les autoritzà amb un Decret $\mathrm{i}$ donà cent lliures per a principiar el fons i capital de dita Obra Pia. ${ }^{31}$ El 9 de gener de 1758, el Sr. Ibarra demanà al Capítol, si volia signar el manament de les cent lliures que havia promès a la Infermeria de la Capella de Música i el Capítol, no sols respongué afirmativament, sinó que féu entrar el notari, el qual "ha prés la paraula". ${ }^{32}$

Malgrat aquest entusiasme inicial, no trigà gaire temps a presentar-se dificultats. En efecte, el 9 de febrer de 1759, així ho manifestava el canonge Protector de la Capella, Sr. Joan Alòs, el qual demanà una Comissió per tractar-ho. I foren anomenats per a la Comissió els canonges Mateu, i Roig. ${ }^{33}$

$5^{\circ}$ : Qualsevol Individuo que no haurá pagat tota la quantitat per sa admissio, si sols la meitat de ella, encara que age pagat los quatre sous mensuals, gozará tant solament de la meitat de la Subvencio, y asistencia, que serán dos sous quiscun dia de sa Malaltia, y tres Lliuras deu sous lo dia del Combregar; pero si está satisfeta tota la entrada de las sinch, ó deu Lliuras respectivas se donarán al Malalt quatre sous cada dia, y set Lliuras en lo del Combre-[f. 426v.]gar.

$6^{\circ}$ : Si la Infermeria se trobás en avant ab fondos bastants per aumentar la Subvencio â sos Malalts, podrá executarse ab la forma que millor li aparexerá.

$7^{\circ}$ : Las utilitats expressadas començará â percibirlas qualsevol Individuo de la Capella desde el dia que fará copnstar ab fe de Metge al S.or Mestre, é Infermers que está Malalt (no de algun resfriat, ó semblant leve indisposicio, que no meresca nom de tal, ni tampoch de Malaltia habitual) fins â sa perfectaa combalescensia, que igualment ab fe de Metge deurán fer constar, y si respecte â la Malaltia, ó Combalescensia ocorrerá alguna dificultat als Infermers pera poder resoldre ab mes acert deurán juntar la Capella.

$8^{\circ}:$ Que del Combregar en avant degan los Individuos vetllar lo Malalt exceptuant lo S.or Mestre per sas ocupacions, Infermers, y Jubilats, seguint los demes per son torn, sens que ningun sen puguia excusar â no tenir un motiu que los imposibiliti, lo que haurán de entendrer lo S.or. Mestre, y Infermers, y trobanto ser aixis, deurán cuidarse continue lo torn que no podrán fer suplir per altre Individuo que no sia de la Capella, altrament dega pagar sis sous aplicadors â la Infermeria, los que se detindrá lo Procurador de la primera paga; y lo Individuo que vetllará degaa lo mati seguent tan solament ferse present.

$9^{\circ}$ : Que en cas de passar â millor vida algun Individuo, se degan donar â la Casa dotse Lliuras per lo enterro si es que agia satisfeta tota la entrada de les deu, ó sinch Lliuras respectivas; y sis Lliuras al que no haurá satisfet mes que la mitat de dita entra$\mathrm{da}$, encara que agia pagadas sens falta alguna las mesadas de quatre sous: Y deurá la Capellaa en lo dia que apareixerá be al S.or Merstre, y Infermers fer un funeral per lo Difunt, y tots los Individuos que â ell faltarán degan pagar sis sous aplicadors â la Infermeria, â no excusarlos llegitim motiu, lo que deurán entendrer lo S.or Mestre, y Infermers, y que degaasistir la Capella al enterro cantant â dos Cors.

$10^{\circ}$ : Per lo govern, y administracio de la Infermeria, se elegirán â pluralitat de vots de la Capella dos Individuos, un Ecclesiastich, y altre Secular per Infermers, dels quals se mudará un cada Any, so es lo mes antich, que si apareixerá be â la Capella lo podrá confirmar.

$11^{\circ}$ : Deurá tambe la Capella anomenar dos Ohidors de Comptes, Ecclesiastich lo un, y Secular lo altre, debentse igualment mudar cada Any lo mes antich, que si apareixerá ba â aquella podrá confirmar, y passarán estos los Comptes cada Any als Infermers; per lo que tindrán estos son Llibre de entrada, y eixida dels diners de la Infermeria, y tindrá facultat la Capella sempre que li apareixerá necessari demanar als Infermers donen reho del estát de sa Administracio principalment per lo que mira als interessos per poder ab est coneixement ordenar lo mes util â la Administracio.

$12^{\circ}$ : Quant algun Individuo que haurá pagat tot lo corresponent â la Infermeria sen anás de la Capella, no podrá pretendrer se li restituesca cosa alguna, y si una volta fora volgues tornari â entrar, deurá pagar de nou la entrada â la Infermeria, y si permaneixent fora continua â pagar los quatre sous mensuals, gozará del Funeral tant solament.

13: Per depositar, y guardar los diners de esta Administracio, se fará una Caxa, que estará sempre en casa lo S.or Mestre, qui tindrá sempre de ella una Clau, y un altre cada un dels Infermers, concorrent sempre tots tres per lo deposit, ó extraccio de la moneda, y si algu de ells se trobará impedit â concorrer, podrá deixar la Clau â altre Individuo de la Capella."

31. SIV. 23 , f. $65 \mathrm{v}$.

32. SIV. 23 , f. $69 \mathrm{v}$.

33. SIV. 23, f. 128. 
Per l'acta capitular del 27 d'abril de 1759, sabem que el canonge Alòs presentà uns additaments a les Ordinacions de la Capella de Música, a l'apartat de la Infermeria, les quals foren aprobades pel Capítol amb signatura i decret del secretari i el segell del Capítol. L'acta afegeix que en quedà una còpia "en esta ma corrent", això és, en la sèrie dels esborranys d'actes, coneguda com Resolucions Capitulars. Els transcric a la nota del peu de plana. ${ }^{34}$

Les Ordinacions de la Capella es guardaven en un armari nou que s'havia construit amb aquesta finalitat, a casa del Mestre de Capella i el 30 d'abril de 1759, el canonge Ibarra, en nom d'Alòs, Protector, digué que les esmentades Ordinacions s'havien florit. I proposà que, tenint un armari ociós (sic) darrera de la porta gran de la Sagristia, s'hi podrien guardar, tant els papers, com els efectes, sense especificar-los, proposta que el Capítol manà que s'executés. ${ }^{35}$

El 18 de gener de 1760, el canonge Vinyes, exposà al Capítol que la Capella de Música pretenia introduir tres punts, en relació a la Infermeria dels músics. Cal fer constar que aquests tres punts no s'expressen a l'acta. El Capítol resolgué deixar-ho a la discreció del susdit Sr. canonge Vinyes. Després, no he trobat cap altra referència als "tres punts". ${ }^{36}$

A la sessió capitular del 5 de maig de 1760, es va presentar una denúncia dels músics de la Capella en contra dels Infermers, els quals havien deixat cent lliures pròpies de la Infermeria, "â certa persona ab fiança de prendas â interés de 3 per 100 secretament, i sens havér juntat Capella" i suplicaven al Capítol que hi posés remei, súplica que fou comesa al Protector de l'esmentada Capella de Música. ${ }^{37}$ El canonge Tagell que n'era el Protector, comunicà al Capítol, segons l'acta capitular del 7

34. SIV. 23, f. 135. I Resolucions Capitulars del 10 Abril 1758 fins 2 de maig 1762”, f. 114s.: [Dia 27 de Abril 1762] "Additament fet â las Ordinacions de la Infermeria de la Capella de Musica de la S.ta Iglesia Cath.l que aprobá lo M.t Il.te Cap.l ab Decret del dia 9 de Desembre 1757, quals junt ab estos nous Capitols confirma, y ratifica, per sa exacta observancia, ab plena inspecció del S.or Canonge Protector, y son los seguents:

$1^{\circ}$ : Que en lo primer dia abil despues de la Octava de la Purissima Concepció se dega juntar la Capella (precehint avis al S.or Canonge Protector) per a fer eleccio de un nou Infermer, y un Ohidor de Comptes que no podran renunciar sens coneixement del S.or Canonge Protector, los quals novament elegits deuran entrar en lo exercici de sos empleos en lo primer dia del any, en lo qual los que acabaran entregaran las claus de la Caixa del Deposit als novament elegits, ab reconeixement del diner existent en Caixa.

$2^{\circ}:$ Que per tot lo mes de Janer se agen de presentar passats los Comptes.

$3^{\circ}$ : Que de aquí en avant donará la Infermeria al Individuo malalt sis sous cada dia de Subsidi, del qual deurá satisfer las visitas del Metge.

$4^{\circ}$ : Que quant ocorria haberhi dos funcions de musica â un mateix temps, lo que correspondria als que estan [f. 114v] ocupats en Siesta, se apliquia â favor de la Capella.

$5^{\circ}$ : Que qualsevol Individuo que se ausentia de esta Ciutat, per â passejar ô per sas dependencias (inseguint lo previngut en lo Capitol 4 de las Ordinacions) sas faltas se apliquian â la Infermeria, pero en cas de necesitar la Capella de algun Musich foraster, â est se paguiaa de la part, que correspondria al Individuo ausent, practicantse lo mateix en cas de ausentarse algun Individuo, pera assistir â alguna funció de musica, ahont tinga sos guanyables.

$6^{\circ}$ : Que qualsevol Individuo, que anirá al Seminari â fer los S.nts Exercicis, ja sie per Ordres, ja per devoció, sie preseent â tots los guanyables, â menos de necesitarse per alguna funció â dit musich foraster.

$7^{\circ}$ : Que quant hi haurá algun Individu malalt, y se necesitia de altre Musich foraster, pera suplir saa falta, en qual cas se donará la part corresponent en aquella funció a dit musich foraster.

$8^{\circ}$ : Que sempre, que los Infermers tingan alguna dificultat que proposar, lo Mestre tinga obligació de juntar la Capella, pera resoldrer, sobre lo proposat, y com assistesca la major part dels Individuos, se age de estar â lo que estos resolguian, procehint coneixement [f. 115] y consentiment del S.or Canonge Protector.

$9^{\circ}$ : Que la Capella tinga un llibre, pera notar en ell sas resolucions, qual llibre deurá estar guardat en la Caixa del Deposit, en que está lo llibre de entrada, y eixida.

35. SIV. 23, f. 136v.

36. Siv. 23 , f. $171 \mathrm{v}$.

37. SIV. 23, f. 186. 
de maig de 1760, que havia arreglat la qüestió dels músics proposada el capítol anterior i es prengué la resolució que, en endavant, els músics, sense permís, o sense ésser-hi present el Protector, no puguessin deixar, ni treure diners de la Caixa, si no fos per subvenció dels malalts. ${ }^{38}$

El canonge Orteu, Protector dels Escolans, féu present, el 8 de juny del 1761, que un dels músics li féu arribar un parell de queixes, la primera referent als ploms que, d'acord amb les Ordinacions de la Infermeria recentment creada, devien aplicar-se a utilitat de la pròpia Infermeria (i aquí calla l'acta). La segona era que el Mestre de Capella havia pretès fer-lo anar en alguna funció a Santa Maria del Mar. El Capítol resolgué que, en la quiestió dels ploms s'estigués a les Ordinacions de la Infermeria i, quant a la resta, ho cometé al Sr. Francesc Orteu, perquè s'informés i obrés el que li sembles més oportú. ${ }^{39}$

Papa: Funerals. Deu tractar-se de Benet XIV, el qual morí el 3 de maig de l'any 1758, ja que el seu immediat successor, Climent XIII, fou papa del 1758 al 1769. En els funerals celebrats a la Catedral, el "salari de la Musica" fou de 6 lliures, com ho acredita l'acta capitular del 27 de juny de $1759 .{ }^{40}$

\section{Cabiscolia.}

A la sessió capitular del 20 de setembre de 1765, es plantejà el dubte de si el Cabiscol podia anomenar substitut seu en les pròpies absències i es resolgué que els Srs. Zeladors consultessin "les obligacions del Capiscol". La persona del "zelador", no m'havia sortit mai, abans d'ara i, per això, no puc explicar quina era la seva tasca, fora del concepte etimològic del mot. ${ }^{41} \mathrm{El}$ document que ara comentaré, acta capitular del 27 de setembre de 1765, diu que els Srs. Mateu, i Roldós, "Zeladors" (equivalent als "Comissionats d'altres vegades?), feren present que, en compliment de la resolució del 20 del corrent, havien examinat les facultats del Cabiscol, pel que feia al nomenament de substitut $\mathrm{i}$ havien trobat que podia anomenar-lo, però que devia proposar-lo al Capítol, perquè l'aprobés. Aquest els donà les gràcies i aprobà el canonge Gualdo, proposat pel Cabiscol. Al document es parla d'algun altre assumpte que no té res a veure amb la música i per això el deixo. ${ }^{42}$

\section{Succentoria.}

Presentació de la Succentoria. L'acta capitular del 6 de juliol de 1761, planteja la qüestió sobre la presentació de la Succentoria. És a dir, si era dret del Sr. Cabiscol o del Capítol. Donava el cas, que el dia anterior s'havien publicat edictes per cobrir la plaça i, pel que sembla, no ho havia fet el Capítol, sinó el Cabiscol. El Capítol encarregà uns Srs. Comissionats, perquè s'informessin i n'informessin el més aviat possible, per tal que no sorgissin perjudicis i poder presentar demanda al Sr. Vicari General, abans no expirés el temps donat pels cartells de la convocatòria, als quals Comissionats se'ls instava que acompanyessin llur comunicació, juntament amb el paper que es llegí en

38. SIV. 23, f. 187.

39. SIV. 24, f. 30.

40. SIV. 23, f. $143 \mathrm{v}$.

41. SIV. 24 , f. $276 \mathrm{v}$.

42. SIV. 24, f. 277. 
capítol als advocats. ${ }^{43}$ L'acta del 26 d'abril de l'any següent, això és, del 1762, expressa la necessitat que es sentia de compilar les Constitucions de la Catedral i el vot dels advocats sobre la llibertat del Capítol per a presentar la Succentoria. Però també es reconeix que s'havien trobat diferents documents a favor de la Succentoria. El Capítol, doncs, tenia dret en el cas que el Cabiscol no l'oferís a cap canonge. ${ }^{44}$ El 7 de maig del mateix any 1762, ja es féu una lectura de les susdites Constitucions per a la Succentoria i es creà una comissió formada pels canonges Sentmenat, Tagell i també Pou. ${ }^{45}$

D'altra banda, el canonge Nadal féu present, el 7 de maig de 1762, que el Sr. Bisbe, després d'estudiar els papers del vot dels advocats, papers que el Capítol li havia tramès sobre la Succentoria, demanava dues Constitucions que s'hi citaven, pel que feia a l'esmentada Succentoria. Es tractava de la Constitució que comença "Ad decorem", data 20 de maig de 1526 i les Lletres de l'Em.m Llegat $a$ latere, cardenal Salviati, data "Kalendas de 7.bre de 1526". Foren comissionats a tal efecte, els Srs. Arxivers. ${ }^{46}$ Uns mesos després, el 22 d'abril de 1763, el mateix Sr. Bisbe demanava tres actes de possessió de la Succentoria, l'un de l'any 1612 (es donà la possessió a Jaume-Àngel Tàpies, qui havia estat mestre de Capella); l'altre l'any 1633 (en prengué possessió Fructuós Tos, com a coadjutor d'en Tàpies); i el tercer, l'any 1636, el mateix Fructuós Tos en fou designat titular, post mortem de Tàpies. D'aquests darrers tres actes, en parlo a la meva tesi doctoral, pp. 48 i 49 , respectivament. ${ }^{47}$

\title{
Succentors.
}

Francesc FONRODONA/FONTRODONA. El 18 de juny de 1761, després de l'Ofici, es tingué un parlament, en què es comunicà el decès del succentor Vilar, el qual havia ocorregut la nit anterior, entre vuit i nou i es prengué l'acord de fer l'absolta aquell mateix dia i al dia següent l'enterrament i el funeral, tot d'acord amb els costums de la Catedral, encarregant al canonge Fontrodona la cura dels serveis i obligacions de la Succentoria, durant la vacant. I es demanà al Secretari que mirés si, quan vacà la Cabiscolia, es féu formal nominació a favor del canonge, al qual s'encarregaran els serveis d'aquesta Dignitat. ${ }^{48}$

Trobant-se malament el canonge Fontrodona i no assistint al Cor, ni tenint la cura deguda de la responsabilitat que comportava la delegació que tenia de la Succentoria, el Capítol decidí, el dia 23 de juliol de 1764, que el Sr. Vicari General enviés un avís al susdit Fontrodona, perquè decidís, si podia, o desitjava continuar en la sustitució de la Succentoria i administració de les rendes, o si preferia deixar-ho. ${ }^{49} \mathrm{Al}$ dia següent, això és, el 24 de juliol del mateix any, en un Parlament en la sagristia, es comunicava la resposta de Fontrodona, el qual reconeixia que es trobava malament i que no podia continuar en l'exercici de la substitució de la Succentoria. El Capítol decidí tractar-ho en altra sessió capitular, però encarregà al canonge que aleshores era el President del Cor, que convidés algun capitular, perquè suplís aquell càrrec. ${ }^{50}$ Uns dies després, el 30 del mateix mes i any, el canonge Nadal féu present que en el Parlament anterior, havia rebut la comissió de trobar subjecte substitut de Fontrodona. El Capítol va ampliar la comissió també al canonge Pou. ${ }^{51}$ Ambdós comissionats

\author{
43. SIV. 24 , f. $36 \mathrm{v}$. \\ 44. SIV. $24,75 \mathrm{v}$. \\ 45. SIV. 24, f. $78 \mathrm{v}$. \\ 46. SIV. 24 , ff. 76. i $78 v$. \\ 47. SIV. 24, f.143v. \\ 48. SIV. 24, f. 32 . \\ 49. SIV. 24, f. 213. \\ 50. SIV. 24 , f. $213 \mathrm{v}$. \\ 51. SIV. 24, f. $214 \mathrm{v}$. \\ 52. SIV. 24 , f. $215 \mathrm{v}$.
}


s'ìnformaren, sobre quin canonge es voldria fer càrrec de la substitució de la Succentoria i, el 3 d'agost, manifestaren que, només el canonge Vinyes estava disposat a ajudar-hi, quan pogués, degut als molts càrrecs que tenia i que els altres canonges tots s'havien excusat. Es recomanà novament als mateixos Srs. comissionats que insistissin a trobar el substitut escaient. ${ }^{52}$ Finalment, el 13 d'agost, Nadal i Pou feren relació de les seves gestions i proposaven les persones que s'havien compromès parcialment a fer la substitució. Així, doncs: el canonge Mateu es responsabilitzava de portar Capa a matínes i laudes els dies, en què hi hauria "Plata en lo Altar Major"; el canonge Francesc Beccar, entonaria tèrcia, els dies de solemnitat i portaria capa en les processons i en tots els aniversaris; el Sr. Joan Marimon, portaria capa en totes les vespres solemnes; i el Sr. Salvador Clariana es cuidaria dels enterraments. Un cop donada aquesta informació, demanaren que fos aprobada. El Capítol donà les gràcies, tant als comissionats, com als esmentats Srs. que acceptaven la substitució. ${ }^{53}$

Josep VILAR. El 13 d'agost de 1756, va demanar llicència i presència, i li fou concedida, per anar fora Ciutat, per raons de salut. ${ }^{54}$

Encara que no relacionada amb la música, la notícia següent formava part de les responsabilitats i confiança que el Capítol li donava. Efectivament, en la sessió capitular del 25 de novembre de 1757, féu relació de la seva participació al Concili de Tarragona, en el qual Concili presentà els comptes, com a Comissionat i Síndic, per part del Capítol de Barcelona. Reconegué que algunes partides que creia bonificables, no ho foren i, en canvi, altres que no les creia bonificables, ho foren. També digué que li posaren dificultats en el reconeixement del poders que presentava, per no coincidir ("concebir", diu el text) les circumstàncies i clàusules amb els dels altres Síndics, especialment l'obligació de la persona i, en conseqüència, no les volien admetre. Que parlà amb el Sr. Bisbe de Vic i es va aconseguir el sanejament de les dificultats, prometent el susdit Succentor que es procuraria del M. I. Capítol una "ratihabició" i així, li fou admesa la Procura i els poders. ${ }^{55}$

El document següent, acta capitular del 18 de juny de 1761, ens assabenta del decès de Josep Vilar, Succentor i diu que havia ocorregut entre vuit i nou de la nit anterior. El Capítol resolgué els detalls, pel que feia a l'absolta, enterrament i funerals i encarregà la succentoria, mentre duraria la vacant, al canonge Fontrodona. ${ }^{56}$

Josep FONT. Fou aquest canonge el presentat per a la Succentoria pel Cabiscol Quintana, tot fent ús del privilegi que tenia el Cabiscol, com es llegeix a l'acta capitular del 19 de juny de 1761. El Capítol, bo i reconeixent aquest privilegi, es plantejà alguns dubtes, sobre tot si aquest nomenament seria perjudicial al Capítol, ja que anava contra les Constitucions que manaven que les Dignitats es donessin a canonges "actu prebendados", sense cap intenció d'agraviar el canonge Font, qui era la persona proposada, ni les seves circumstàncies personals. En conseqüència, es decidí ajornar el nomenament, fins a tant la Comissió formada pels Srs. Arxivers i el Secretari, no ho haguessin esbrinat. ${ }^{57} \mathrm{El}$ dictamen final dels advocats, com es llegeix a l'acta capitular de 20 de juliol de 1761 fou, que devia mantenir-se la presentació del Sr. canonge Josep Font i Carveró, ja que la Succentoria no estava compresa en els Estatuts que disposaven que les Dignitats s'havien de donar a canonges actuals i, a més, constava de provisions de dita Succentoria fetes a persones que no eren canonges. El Capítol resolgué que s'acceptés el dictamen dels advocats. ${ }^{58}$

N. MATEU. Aquest canonge que s'havia ofert per fer la substitució del Succentor Fontrodona, a Matines, manifestà, el 5 d'octubre del mateix any 1764 , que ell només s'havia compromès temporalment a fer aital substitució i que, no podent-la fer més temps, per causa de les moltes obligacions que tenia, demanà que en nomenessin un altre, al seu lloc. El Capítol deixà en mans dels canonges comissionats, Nadal i Pou, la tasca de trobar-li el substitut. ${ }^{59}$ Tres dies després, això és, el 8 d'octubre, el canonge Nadal, un dels comissionats, expo-

53. SIV. 24 , f. 216.

54. SIV. $22, \mathrm{f}, 158 \mathrm{v}$

55. SIV. 23, f. 63.

56. SIV. 24 , f. 32 .

57. SIV. 24 , f. 32 .

58. SIV. 24 , f. 39.

59. SIV. 24, f. 222. 
sà al Capítol que, havent experimentat la vegada anterior la dificultat de trobar substitut per a la Succentoria, demanava d'ésser exonerat d'aquesta comissió. Però el Capítol insistí a renovar-la, tant a ell, com a Pou ${ }^{60}$ En la sessió del dia 12 d'octubre corrent, Nadal i també Pou, manifestaren al Capítol la sospita que tenien, pel que feia a la dificultat de trobar el substitut que cercaven per a la succentoria, de que ningú no gosava d'acceptarho, per no carregar-se la responsabilitat "de fer la Oració per Nadal" i entenien, en conseqüència que, en primer lloc, s'havia de deixar ben clar, si el que feia de Succentor a Matines, "está, ô no obligat â fer dita Oracio". I el Capítol decidí tractar-ho en un capítol posterior. ${ }^{61} \mathrm{I}$, en efecte, el 7 de desembre del mateix any, hom llegeix a la corresponent acta capitular, que el Capítol decidí de cercar qui faria l'esmentada Oració. ${ }^{62}$

\section{Mestre de Capella}

Josep PUJOL. El 5 de juliol de 1758, el Mestre de Capella comunicà al Capítol que s'havia espatllat el violó gran, propietat del Capítol i que, si semblava bé, es podria fer reparar. La solució fou comesa al Protector de la Capella. ${ }^{63}$ Aquest, dos dies després, comunicava al Capítol que per a la reparació del violó gran o contrabaix, li havien demanat 24 peces de 8 antigues i ho deixaren a la seva discreció. ${ }^{64}$

També el 15 de setembre de 1758, el Mestre de Capella, Josep Pujol, féu present, que la Capella estava totalment mancada de subjectes violinistes, raó per la qual no se'n podia deseixir en les funcions i suplicava que s'hi donés providència. També aquesta súplica, com era natural, fou comesa al Protector de la Capella. ${ }^{65}$

Encara que no es diu el per què, l'acta capitular del 13 de novembre de 1758, recull el permís que donà el Sr. Alòs, com a Protector de la Capella, al Mestre de Capella, per absentar-se alguns dies, permís que aprobà també el Capítol. ${ }^{66}$

El 29 de març de 1759, el Sr. Protector de la Capella comunicà als Srs. Capitulars que el Mestre havia compost "lo To del Vexilla al de lo Tomas" i que, si semblava bé, s'interpretaria com s'havia ideat. Fou resolt que es deixés a la discreció del Mestre de Capella. ${ }^{67}$ Resulta curiosa aquesta notícia, a causa del que diré tot seguit. "Lo dia 6 de mars de 1758 â 8 horas i quart, y 8 Minuts del Mati se rompe la campana major dita Thomas...". Refundida per "Joseph Barnola Fundidor del Rey", la nova fou beneïda, el 22 de juliol del mateix any (v. Exemplària, 6, f. 100) i, molt probablement, en homenatge del nou Tomàs, Pujol va compondre aquest Vexilla, afinat al to de la campana, la qual fou afinada al to de "Re 3". Repassant les fitxes del canonge Bonaventura Ribas, hom comproba que, a partir del 23 de novembre de 1823, és coneguda com "La Tomasa" i la defineix dient que "se distingue por su tono grave y excelente sonoridad". En la recerca d'aquestes notícies sobre la campana, m'ha ajudat el Dr. Josep Baucells, savi Arxiver de l'Arxiu de la Catedral i bon amic i company de Capítol. "El Tomàs" és la campana gran de la Catedral. Actualment, aquesta campana, es diu "La Tomasa".

El 25 de juny del 1762, el Protector Sr. Joan Alòs féu arribar al Capítol queixes en contra del Mestre de Capella, en el sentit que havia abandonat l'ensenyament als escolans i no els donava moltes lliçons. En aquesta ocasió, el Capítol comissionà el Sr. Tagell, perquè comuniqués al Mestre les queixes i li digués que, si no complia millor, es prendrien altres mesures. ${ }^{68}$

60. SIV. 24, f. 223.

61. SIV. 24, f. 224. Confesso que, fins ara, no havia trobat aquesta càrrega acumulada a la Succentoria i, per tant, no puc explicar en què consistia.

62. SIV. 24, f. 231

63. SIV. 23, f. 99.

64. SIV. 23, f. 99v. No sé, si aquesta quantitat es correspon amb la cita que donaré tot seguit, agafada de la Gran Enciclopèdia Catalana. "Peça de quatre escuts o de vuit rals forts referint-se a la mitja unça o al duro, respectivament". Si més no, pot ser un referent.

65. SIV. 23, f. $109 \mathrm{v}$.

66. SIV. $23, \mathrm{f}, 113 \mathrm{v}$

67. SIV. $23, \mathrm{f}, 133$.

68. SIV. 24, f. $92 v$. 
Les mares dels Mestres de Capella, quan aquests en tenien, probablement vivien amb el seu fill i tenien cura de la casa. Sembla que també es cuidaven de rentar, planxar, etc. la roba dels escolans de grana que vivien a casa del Mestre i, com es dedueix dels llibres de comptes, sobre tot dels de l'Administració dels Escolans, cobraven quelcom per aquestes feines. Així, doncs, coneixem el nom d'alguna mare de Mestre de Capella. En el cas present, vull fer constar un autògraf de la mare d'en Josep Pujol. Diu: "Maria Anna Pujol", mentre que en altres documents, hom llegeix: "Mariagna" (Agna = Agnès?), però, podria "Agna" ser una corruptela fonètica d"“Anna"?

\section{Organista}

Francesc MARINER. L'organista Francesc Mariner fou nominat examinador per a la provisió de l'orgue de la Catedral de Girona i demanà permís per absentar-se el temps necessari, com es llegeix a l'acta capitular del 16 de gener de 1758. A canvi, prometia que deixaria un substitut idoni, per al servei de la Catedral, permís que el Capítol li concedí. ${ }^{70}$

L'acta capitular del 31 d'agost de 1759, recull la petició de Mariner, perquè el Capítol li concedís la presència, "infirmitatis causa", tot presentant la corresponent fe de metge. El Capítol, evidentment, li concedí la presència. ${ }^{71}$

El Capítol de Toledo oferí a Mariner la plaça d'organista segon, dotada amb la quantitat de mil ducats, com consta per l'acta capitular del 11 de gener de 1765. Mariner demanà al Capítol que l'aconsellés sobre la decisió que hauria de prendre, ja que eren molts els honors particulars que li devia i no volia ser titllat de desagraït. El Capítol li respongué que considerava l'atenció, però que la decisió era cosa molt personal seva, ja que tocava al seu interès. ${ }^{72}$

\section{Diaconal}

Joan CAMPÀ. El diaconal Joan Campà, al qual ja coneixem per la seva malaltia crònica, demanà novament llicència, presència i estipendi de missa, per necessitar dels banys i al seu temps de la brisa. Acompanyava la petició amb la fe del metge, d'acord amb l'acta capitular del 20 d'agost de 1756. El Capítol li concedí la llicència i la presència, però no l'estipendi, aquesta vegada. ${ }^{73}$ Igualment ocorregué els anys següents de $1757^{74}$, $1758^{75}, 1759^{76}$ i $1760^{77}$.

A la sessió capitular del dia 17 de juny de 1765, fou llegida una súplica de Campà, amb què demanava la jubilació de la assistència a les funcions de la Capella, a la qual havia servit durant 55 anys. El Capítol resolgué que li diguessin que li signaven la súplica, d'acord amb les Ordinacions, o Constitucions de la Capella i que, signada, la passaven al Sr. Protector de la Capella. ${ }^{78} \mathrm{El} 30$ de setembre d'aquest mateix any, el Sr. Gaspar Bastero féu relació del Memorial de mn. Joan Campà, Diaconal, el qual li fou comès el susdit 17 de juny i manifestà que li semblava que se'l podia dispensar els dies de mal temps, en les funcions celebrades fora de la Catedral i sempre que es judiqués prudentment que agreujaria les seves indisposicions. El Capítol aprobà aquesta proposta del Sr. Bastero. ${ }^{79}$

\footnotetext{
69. $\mathrm{AE}, 1760 / 61, \mathrm{~s} / \mathrm{f}$

70. SIV. 23 , f. 71.

71. SIV. 23 , f. 151

72. SIV. 24 , f. $233 \mathrm{v}$

73. SIV. 22, f. 159v.

74. SIV. 23, f. 56

75. SIV. 23, f. $108 \mathrm{v}$.

76. SIV. 23, f.150v.

77. SIV. 23, f. 209v

78. SIV. 24 , f. 260.

79. SIV. 24, f. 278.
} 


\section{Subdiaconal}

Josep SARENANAN. L'acta capitular del 27 d'agost de 1756, diu que aquest subdiaconal, havent sabut que la Capella estava mancada de contralts, demanà ser admès per aquest ofici, encara que s'havia oposat al subdiaconal. El Capítol li respongué que no hi havia lloc, de moment. ${ }^{80}$

\section{Escolans de cota de grana}

Sepultura al Claustre. El 10 de maig de 1756, el canonge Roldós, com a Obrer Major i en nom dels Obrers Majors, demanà al Capítol, per als "Criats dels S.ors Capitulars", "alguna Sepultura dels Claustros pera enterrarse”, però que aleshores no n'hi havia cap de disponible. Tanmateix, proposà que la dels Escolans de Cota de grana, la qual feia molts anys que no servia, podria servir també per als "Criats Patges", gràcia que el Capítol concedí. ${ }^{81}$

Llits. El dilluns 26 de juny de 1758, el canonge D'Alòs, Protector de la Capella, es queixà en capítol, de la incomoditat en què dormien els escolans de Cota de grana i dels inconvenients espirituals que se'n podien derivar del fet de dormir-ne tres en un mateix llit, raó per la qual havia reprès diferents vegades al Mestre, sense que aquest hagués esmenat la falta. Havent estat, doncs, inútils totes aquestes prevencions, ho proposava, perquè el Capítol hi donés la providència més oportuna. I el Capítol ho deixà novament a mans del Sr. Protector, perquè hi donés la solució que cregués més oportuna. $^{82}$

Cotes negres. El 13 de maig de 1757, el Sr. Albert Ibarra, Protector dels Escolans, féu present que aquests "tenian ja molt passadas las Cotas negras" i el Capítol resolgué que els en fessin de noves, a discreció del susdit Sr. Albert. ${ }^{83}$ Aquest mateix Sr. passà compte, el 16 de desembre del mateix any, de les cotes negres dels Escolans de grana, el qual compte pujava fins a 59 lliures, 18 sous i 5 diners que el Capítol ordenà abonar. El Notari prengué acta d'aquesta resolució capitular. ${ }^{84}$

També, el 12 de març de 1761, el canonge Tagell demanà que es fessin cotes negres als Escolans de grana i el Capítol s'hi avingué. ${ }^{85}$ Molt probablement, el Manament que es féu "contra lo Caritater", el dia 26 de juny del susdit any, perquè pagués les cotes negres dels Escolans, fa referència a la resolució anterior del 12 de març. En aquest cas, l'import fou de 45 liures. $^{86}$

Llicència a un Escola de grana per anar a cantar un Ofici en una Torre. El Mestre de Capella demanà llicència al Capítol, el dia 26 de novembre de 1759 , perquè un escolà de cota de grana l'acompanyés a cantar un ofici en la Capella de la torre de D. Manuel Palacios, llicència que el Capítol atorgà. ${ }^{87}$

Malaltia dels Escolans de Cota de grana. “Roña”. El dia primer de maig de 1762, el Sr. Francesc Orteu féu present que aquell mateix matí s'havia assabentat que els Escolans de cota de grana

\footnotetext{
80. SIV. 22 , f. $161 \mathrm{v}$.

81. SIV. 22, f. 135.

82. SIV. 23 , f. $98 \mathrm{v}$.

83. SIV. 23 , f. $34 \mathrm{v}$.

84. SIV. 23 , f. $67 \mathrm{v}$.

85. SIV. 24, f. 13.

86. SIV. 24 , f. 34.

87. SIV. 23 , f. $166 \mathrm{v}$.
}

86

(c) Consejo Superior de Investigaciones Científicas Licencia Creative Commons 3.0 España (by-nc)
Anuario Musical, 60 (2005)

http://anuariomusical.revistas.csic.es 
tenien "roña" i que, havent interrogat el cirurgià, aquest li havia confirmat "ser roña, y de mala qualitat"; que semblava que ja feia dies que patien aquest mal i que el Mestre no li havia dit res. El Capítol resolgué fer comissió als canonges Sr. Tagell i Sr. Orteu, perquè prenguessin les providències més convenients i que el Sr. Nadal enviés a cercar el Mestre i li donés una "correcció forta", per no haver avisat al Protector de la Capella. ${ }^{88}$

En relació amb la qüestió de les providències preses, pel que feia a la malaltia dels Escolans, es tingué un parlament a la Sagristia, després de Completes, el mateix dia primer de maig. En aquest parlament, presidit pel Sr. Vicari General, el comissionat Sr. Francesc Orteu digué que havia fet treurer les Cotes de grana de la Caixa de la Sagristia i que el Mestre li demanava com s'ho faria per cantar les Matines i el dia de Santa Creu, sense els escolans i que el seu metge, Dr. Comas -el del Mestreli deia que els escolans no patien aqueix mal. I també digué que, per totes aquestes raons, havia preparat per al dia següent, una consulta dels Doctors en Medicina Fornès, Esteva i Comas i els Cirurgians Carles Grassot i Paissa, perquè declaressin, si era o no era roña, el mal dels Escolans. El Capítol aprobà la consulta, però ordenà que Orteu hi fos present. ${ }^{89}$

El 7 del mateix mes i any, el Sr. Orteu féu relació de la consulta haguda, en la qual intenvingué també el cirurgià Capdevila, els quals convingueren que realment es tractava de "roña, y de mala especie", la malaltia dels escolans i que, per curar-los, s'haurien de fer molts remeis i, durant aqueix temps, no podrien assistir al Cor, ni a cap altra funció. També diagnosticaren que el "Vice-Mestre", o "Sota-Mestre", una neboda del Mestre i una tercera persona de dita casa, patien el mateix mal i s'havia resolt en l'esmentada consulta, donar també remei a aquests tres. Pel que feia al Mestre, el disculparen de responsabilitat, ja que el seu metge, Dr. Comas, sempre li havia dit que els escolans no tenien aqueix mal. El Capítol acceptà el dictamen dels Doctors i també sufragar les despeses per als remeis de tots els malalts. ${ }^{90}$

Apropant-se els dies de les lletanies, els escolans de grana, indisposats, no volgueren perdre del tot els "lucros" que obtenien en el repartiment de les "toyas", acte que corria a càrrec seu i demanaren, el dia 18 de maig de 1762, que, si per alguna causa, la processó no sortís de la Catedral, els escolans morats els substituïssin i es repartissin les "toyas", però que els "lucros" fossin per als morats i per als de grana ${ }^{91}$. El Capítol resolgué "concedir la gracia â la direccio del S.or Fran.co Orteu" ${ }^{92}$

El 9 de juny de 1762, el canonge Orteu comunicà al Capítol que els escolans estaven ja curats de sa malaltia, però que els metges deien que hi havia possibilitat "q.e tornás â reverdirse lo mal" i, per la seva part, el Mestre de Capella no trobava minyons per cantar en l'octava de Corpus i que, puix estaven curats, podrien assistir aquella mateixa tarda a Matines i, després, continuar normalment. El Capítol resolgué, doncs, que anessin a cantar. ${ }^{93}$

88. SIV. 24, f. $77 \mathrm{v}$.

89. SIV. 24, f. $77 \mathrm{v}$.

90. SIV. 24 , f. $78 \mathrm{v}$.

91. Per curiositat, he repassat el Costumari Català, de J. Amades i en el vol II, p. 962ss., parla de la setmana de l'Ascensió, coneguda com la setmana de les lletanies, molt interessant, com sempre, però no al-ludeix per a res a les "toies" i "lucros" dels escolans. D’aquests només diu que, damunt de les tovalles que convertien el pedró en altar per a la missa, en les processons pel camp, "els escolanets posen dos canelobres". També diu que, a Barcelona, aquestes processons anaven, un dia, de la Seu a Santa Maria del Mar i, l'altre dia, de la Seu a Santa Maria del Pi.

92. SIV. 24, f. 81 .

93. SIV. 24 , f. 87. 
El canonge Tagell, Sagristà major i Protector dels Escolans, proposà, el dia 25 de juny de 1762, que, donat que els escolans ja estaven bons, es podrien fer obres a la casa del Mestre, per tal que cada escolà tingués la seva pròpia habitació i el seu propi llit, per evitar que dormissin dos en cada llit i, fins i tot algun cop, tres. I també que els fessin roba. Quant a les obres i llits, el Mestre pagaria la part que li correspongués i la resta el Capítol. El Capítol aprobà aquest plantejament i encarregà la realització al susdit Tagell. ${ }^{94}$

Roba. Hom llegeix, a l'acta capitular de 22 d'octubre de 1762, que el canonge Tagell proposà un llistat de roba que es necessitava per als quatre escolans, això és: “ tres Casacas, quatre Cal-/sas, y una Jupa de paño, y quatre Jalecos de Vayeta", essent l'import total de 72 lliures, d'acord amb el pressupost del sastre. El Capítol resolgué que es fes la roba expressada, deixant-ne l'execució al susdit Tagell. ${ }^{95}$

Cotes de grana. El canonge Alòs, Protector dels Escolans, manifestà al Capítol, el dia 11 de maig de 1764, que les cotes de grana dels escolans eren molt velles i de difícil composició i proposà, en conseqüència, de fer-ne de noves i compondrer, en la mesura del possible, les velles, les quals servirien per als dies ordinaris. Hi hagué resolució favorable i es deixà l'execució al susdit Alòs. ${ }^{96} \mathrm{El}$ mateix canonge Alòs proposà, en el capítol del 20 de juny següent, que si el Capítol tingués a bé, faria portar una caixa que hi havia a la fusteria, a casa del Mestre, per guardar-hi les cotes noves de grana. El Capítol deixà novament l'execució a les seves mans. ${ }^{97} \mathrm{El} 26$ d'octubre del mateix any, el propi Alòs presentà el compte de les Cotes de grana -84 lliures-i el del sastre -22 lliures, 10 sous i 11 diners-. El Capítol li demanà que mirés, si podia rebaixar quelcom en el compte del sastre. ${ }^{98} \mathrm{El} 5$ de novembre següent, Alòs notificà al Capítol que el sastre només estava disposat a rebaixar una lliura. Es resolgué, doncs, que s'abonessin els susdits comptes i que fos a càrrec de la Caritat. El Notari en prengué nota. ${ }^{99}$

Protector dels Escolans, de la Capella i dels Músics. El Sr. canonge Roldós féu present, en la sessió capitular del 29 d'abril de 1763, que, havent estat elegit Protector dels Escolans, per al bienni 1763-1765, volia saber, si això comportava també ser Protector de la Capella i/o dels Músics, abans de jurar dit ofici, ja que li restava algun dubte, respecte d'alguns detalls que havia observat i voldria asseguar-se'n abans, per al seu govern i compliment del susdit ofici. Després, doncs, d'haver-hi discorregut, fou resolt que el Protector dels Escolans havia de tenir cura i era Protector, també, de la Capella i/o dels Músics. ${ }^{100}$

Medicines. El Sr. Alòs, Protector dels Escolans de grana presentà, el 14 de gener de 1765, un compte de les medicines que els escolans de grana havien gastat durant dotze anys, essent-ne l'import del qual 76 lliures i digué que el metge Dr. Joan Esteve diu que l'apotecari es pot donar per ben pagat amb la tercera part, però que l'apotecari no vol cobrar menys de la meitat. El Capítol ho deixà al bon

94. SIV. 24 , f. $92 \mathrm{v}$.

95. SIV. 24, f. $112 \mathrm{v}$.

96. SIV. 24, f. 203.

97. SIV. 24, f. 209.

98. SIV. 24 , f. $225 \mathrm{v}$

99. SIV. 24, f. 226.

100. SIV. 24, f. 144 . 
fer del Sr. Alòs. ${ }^{101}$ El nou informe d'Alòs, quatre dies després, això és, el 18 de gener, fou que l'apotecari no volia cedir més de la meitat i es féu Manament que recollí el Notari. ${ }^{102}$

\section{Noms i notícies d'escolans de cota de grana}

Josep PUIG. Francesc Gualdo i també Companys signen un rebut per roba que ha servit per vestir aquest escolà quan acabà la veu. L'import era de 20 lliures, 9 sous i 9 diners, al qual compte li fou sumat altre compte anterior d' 1 lliura, 17 sous i 6 diners, essent-ne l'import total de 22 lliures, 1 sou i 3 diners. ${ }^{103} \mathrm{El}$ segon compte es troba detallat en altre lloc, on diu que responia al preu d'un"sombrero" que serví per a Josep Puig que ha acabat la veu. Porta data de 6 de maig de 1751. ${ }^{104}$

Anton PUIG. Sembla que al temps del document que ara comentaré, consta que Antonia Montserrat rebé, per Anton Puig, la quantitat de 4 lliures, 4 sous i 6 diners, import de dues camises que havien servit per a aquest escolà. La data és del 24 de desembre de 1754. Probablement l'Antonia Montserrat era la botiguera i el motiu no consta. Per tant, no es pot assegurar que fos en ocasió d'haver acabat la veu. ${ }^{105}$

Jaume BARTRA. El nom d'aquest escolà, no apareix al llistat d'escolans de la meva darrera publicació, podria tractar-se, però, d'un dels dos anònims que hi apareixen sota la fòrmula N. N. En el present document, el mestre Josep Pujol reclama per a ell "la caritat acostumada", pel fet d'haver acabat la veu. El Capítol resolgué concedir-la-hi. L'acta correspon al dia primer d'abril de $1756 .{ }^{106}$

Mateu MULLARACH / MULLERÁT / MOLLERAT. Sota aquesta varietat de grafies d'aquest cognom, s'amaga, sense cap mena de dubte, una mateixa persona, però no goso dir quina era l'autèntica, per manca de més documentació. L'important és que apareix en ocasió d'haver acabat la veu i de demanar el Mestre per a M. Mullerat la caritat acostumada a donar als altres, el 2 de juny de 1756. El Capítol ho cometé al Protector de la Capella i li demanà que s'informés si era veritat que havia acabat la veu ${ }^{107}$ El Mestre la va tornar a demanar amb Súplica i el Capítol la hi concedí, com consta a l'acta capitular del 23 de gener de $1757 .{ }^{108}$ A l'Administració dels Escolans dels anys 1756-1757, sense que hi consti el dia i el mes, hom hi troba el compte de 29 lliures i 4 sous, rebut per Jaume Mollerat, pare de Mateu Mollerat, escolà, en concepte del vestit del fill, quan acabà la veu. ${ }^{109}$

El 12 de juny del 1758, el canonge Vinyes digué al Capítol que Mateu Mullarach demanava amb Súplica que li fossin donades d'una sola vegada les 75 lliures que s'acostumava a donar en tres pagues, als escolans que havien acabat la veu i el Capítol decidí que no tenia lloc, sinó que li donessin en la forma acostumada. ${ }^{110}$

Juan B.ta Francesch. Davant del dubte de si "Francesc" li era nom o cognom, prefereixo deixar-ho com a nom. El 16 de febrer de 1758, el Mestre Josep Pujol comunicà al Capítol que havia acabat la veu i demanava per a ell la caritat acostumada, gràcia que el Capítol atorgà. ${ }^{111}$

Josep SERRA. També el Mestre intercedí a favor d'aquest escolà que havia acabat la veu i demanà per a ell la caritat acostumada, el dia 12 de juny de 1758. El Capítol ho cometé al Protector de la Capella. ${ }^{112}$ Dos dies després, el 12 dels susdits mes i any, el canonge Joan d'Alòs que era el Protector de la Capella i en tenia la Comissió, manifestà al Capítol que Josep Serra no havia servit tot el temps necessari per meréixer la remunera-

101. SIV. 24 , f. $234 \mathrm{v}$.

102. SIV. 24 , f. $235 \mathrm{v}$.

103. AE. $1750-1751$, f. $11 \mathrm{v}$.

104. AE. $1750-1751$, f. 12 .

105. AE. $1754-1755$, f. $7 \mathrm{v}$.

106. SIV. 22, f. $125 \mathrm{v}$.

107. SIV. 22, f. 141v.

108. SIV. 23 , f. 5.

109. AE, 1756-1757, f. 5.

110. SIV. 23 , f. 95.

111. SIV. 23, f. 75.

112. SIV. 23 , f. $94 \mathrm{v}$. 
ció que donava el Capítol i proposà que si li donaven la tercera part, ja seria un premi proporcionat al que es donava, en acabar els tres anys i que el vestit fos d'inferior qualitat, proposta que avalà el Capítol. ${ }^{113}$

Magí VIDAL i Francesc GUITART. En ocasió d'haver acabat la veu, aquests minyons de cota de grana, el Mestre de Capella, demanà per a ells, com es llegeix a l'acta capitular del 10 de novembre de 1760, la caritat que es solia donar. El Capítol cometé la súplica al canonge Protector de la Capella de Música. ${ }^{114} \mathrm{El}$ canonge Tagell que devia ser el Protector de la Capella, en virtut de la comisió rebuda, informà al Capítol, el dia 14 del mateix mes i any, que, d'aquests dos escolans, l'un portava sis anys de servei i l'altre, quatre. El Capítol els concedí tot allò que s'acostumava a donar als escolans de grana, en aqueixes circumstàncies. ${ }^{115}$

Pel document corresponent, consta que reberen 50 lliures cadascun, el dia 14 i 15 de desembre, respectivament, de l'any 1760, en ocasió d'haver acabat la veu i pel vestit que els corresponia. ${ }^{116}$

Francesc Guitart, per la seva banda, demanà al Capítol, el 9 de febrer de 1761, que li volguessin anticipar l'import de la segona paga, ja que necessitava comprar-se un instrument per estudiar i, amb la primera paga havia tingut prou per comprar-se el vestit. El Capítol ho cometé al canonge Vinyes, perquè ho executés, com millor li semblés, d'acord amb la pràctica i estil. ${ }^{117}$ La resposta li fou donada, després que el susdit canonge Vinyes informés al Capítol, el 16 del mateix mes i any, dient que els escolans rebien aquests pagaments -tres-, finit cada un dels tres anys. El Capítol, doncs, resolgué que no s'innovés res i s'estés a l'estil. ${ }^{118}$

Encara insistí, Guitart, el 13 de novembre del susdit any 1761, demanant que li donessin juntes les dues últimes gratificacions, per poder satisfer el deute contret amb la compra de la viola, instrument en què s'exercitava i per poder-se vestir d'hivern, ja que els seu pares eren pobres i no el podien ajudar. I el Capítol ho cometé altre cop al canonge Vinyes ${ }^{119}$, qui obtingué del Capítol, el 27 dels corrents mes i any, en el sentit de que la petició no tenia lloc. ${ }^{20}$

Manuel PLANAS. Escolà de cota de grana i Oboè. Fill del Manuel Planas, contralt i arxillaütista, de qui faig esment en altre indret del present treball. El 9 de novembre de 1761, el Mestre de Capella, Josep Pujol, comunicà al Capítol que, aquest escolà havia acabat la veu i demanava per a ell, la caritat acostumada, petició que el Capítol passà al Sr. Protector de la Capella. ${ }^{121} \mathrm{El} 13$ del mateix mes i any, el Sr. Fc. Orteu informà sobre el Memorial presentat pel Mestre de Capella, en pro d' aquest escolà, el "30 d'octubre", dient que era veritat el seu contingut i el Capítol ordenà que es donés al Planas "lo solit". ${ }^{122}$

El 4 de desembre del mateix any 1761, Planas presentà una Súplica al Capítol, que li fos lliurat en diners l'import del vestit que es donava als escolans, quan acabaven la veu. El Sr. Fc. Orteu avalava aquesta súplica i el Capítol, ho deixà a la discreció d'aquest Sr. canonge. ${ }^{123}$ Coneixent la situació familiar dels Planas, hom entén el gest del minyó.

El 8 d'octubre de 1764, demanà al Capítol el nomenament de Primer Oboè. Adduïa, com a mèrits, el fet d'haver suplit les faltes, absències i malalties del seu difunt pare, el qual havia servit al Capítol com a Contralt (i com a Arxillaütista) i, al present, es trobava amb mare i dues germanes "Donzellas", sense cap més assistència que la que ell podia aportar. El Capítol cometé la súplica al Sr. Protector de la Capella. ${ }^{124}$

\author{
113. SIV. 23, f. 95 . \\ 114. SIV. 23, f. 218. \\ 115. SIV. 23, f. 219. \\ 116. AE. $1760-1761$, f. 12. \\ 117. SIV. 24 , f. 5. \\ 118. SIV. 24, f.6v. \\ 119. SIV. 24, f. 50v. \\ 120. SIV. 24, f. 54. \\ 121. SIV. 24, f. $49 \mathrm{v}$. \\ 122. SIV. 24, f. 51. \\ 123. SIV. 24 , f. $54 \mathrm{v}$. \\ 124. SIV. 24 , f. 222 v.
}

90

(c) Consejo Superior de Investigaciones Científicas Licencia Creative Commons 3.0 España (by-nc)
Anuario Musical, 60 (2005)

http://anuariomusical.revistas.csic.es 
Josep AUMATELL. Document interessant el que ara comento, pels detalls biogràfics que dóna d'aquest nen, ja a l'inici del seu ingrès com escolà de cota de grana, detalls que poques vegades tenim, ni dels mateixos Mestres de Capella. Es tracta, doncs, de Josep Aumatell, d'Olot, de deu anys i mesos, al qual ja havia oït el Capítol. Aquesta notícia es recull a l'acta capitular del 16 de novembre de 1761. En féu la presentació el canonge Orteu i el Capítol li digué que l'admetés en les condicions que ell cregués oportunes. ${ }^{125}$ A més a més, es pot afegir que ocupà la vacant d'en Manuel Planas.

L'acta capitular del 18 de juliol de 1764, en canvi, ens parla d'un Josep Aumatell, conegut com "Josep de Olót", malalt, al qual, per consell del seu metge, li convindria d'anar al seu país "a pendrer los ayres natius". El Capítol deixà la resolució a mans del canonge Joan Alòs. ${ }^{126}$ Uns dies després, el 27 de juliol del susdit any, el canonge Manuel Joven proposà al Capítol que deliberés quin ajut es podria donar a l'escolà de cota de grana d'Olot, al qual es permetia que se n'anés al seu país a recuperar-se, ja que a casa seva eren molt pobres. La resolució que prengué el Capítol, pel que fa a l'escolà, no consta en l'acta capitular. En canvi, per l'acta del 5 de novembre següent, la qual comento tot seguit, sabem quina quantitat invertí el Capítol en la malaltia d'aquest escolà i la d'un altre que fou sacramentat, però no consta si es va refer o si va morir. ${ }^{127}$

El Sr. Alòs presentà, el 5 de novembre de 1764, el compte de les despeses hagudes en la malaltia de l'escolà de cota de grana que, per malalt, s'envià a Olot, la seva pàtria i de l'altre escolà que estigué sacramentat. Importava, en total, 91 lliures, 19 sous i 9 diners. El Capítol resolgué que es pagués el susdit compte, carregant-lo a la Caritat. El Notari en prengué nota. ${ }^{128}$ El canonge Alòs, aprofitant la circumstància de la malaltia d'Aumatell i del seu retorn d'Olot, ja recuperat, insistí en la conveniència de dormir separats els escolans, encara que el Mestre deia que ell només tenia obligació d'oferir dos llits. D'altra banda, l'Aumatell, encara tosia i podria ser-li nociu el cantar i, a més, el mal podia ser contagiós. El Capítol resolgué, pel que feia a Aumatell, que Alòs ho consultés amb el Dr. Esteve i, si aquest hi veia perill, que donessin la caritat acostumada a Aumatell (això volia dir que el tractessin com si hagués acabat la veu) i, quant als llits, es recomanà a Alòs que s'informés de tot i ho exposés en altre capítol. ${ }^{129}$

L'acta capitular del 9 de novembre de 1764, recull la Súplica del Mestre de Capella, amb què manifestava que Aumatell havia acabat la veu i demanava la sòlita caritat. Es resolgué donar-li-la, deixant-ne l'execució al Sr. Protector. ${ }^{130}$

Els pares d'Aumatell també presentaren, el 23 de novembre de 1764, una Súplica al Capítol, avalada pel Rector de la parròquia de Sant Cugat del Rec, amb què exposaven la seva "poca salut i molta misèria" i demanaven, per tal que el seu fill pogués restablir-se més còmodament, que la caritat que el Capítol donava en tres anys als escolans que acabaven la veu, en aquesta ocasió fessin una excepció i els la donessin junta. Així podrien anar-se'n tots junts a Olot, la seva pàtria. El Capítol cometé la Súplica al Sr. Protector de la Capella. ${ }^{131}$ Alòs presentà la resposta, el 26 del mateix mes i any i digué que tot allò que al-legaven els pares de Josep Aumatell era veritat, però que, si els donaven tot l'import d'una vegada, podria ser en detriment del propi minyó i, a més, sentaria exemplar. El Capítol resolgué que li donessin la caritat en la forma acostumada, però que, atesa sa pobresa i la indisposició del minyó, els donessin la primera paga immediatament. ${ }^{132}$

Josep Miquel PRAT / PRATS. El Mestre de Capella presentà una Súplica al Capítol, el 18 d'abril de 1763, fent constar que Miquel Prats, escolà de grana havia acabat la veu i que li donessin allò que s'acostuma-

125. SIV. 24 , f. 52.

126. SIV. 24 , f. 213.

127. SIV. 24, f. 214.

128. SIV. 24, f. 226.

129. SIV. 24, f. 226.

130. SIV. 24, f. $226 \mathrm{v}$.

131. SIV. 24 , f. $228 \mathrm{v}$.

132. SIV. 24 , f. 229. 
va a donar als altres. El Capítol ho deixà a mans del canonge Protector dels Escolans. ${ }^{133}$ Amb la mateixa data, 18 d'abril de 1763, hi ha un rebut, a l'Administració dels Escolans, on consta que aqueix dia es pagaren 5 lliures, 19 sous i 9 diners, a Maria Anna Coll, per tela per a dues camises i dos corbatins i per mans de fer-las, per a Miquel Prat, "escolà que fou de Grana". ${ }^{134}$

L'acta capitular del 4 de juliol de 1764, es fa ressò de la següent petició d'aquest escolà. Diu que servia la Capella de Música, des dels vuit anys, primer com a Tiple, després com a escolà de grana $i$ aleshores ho feia tocant el violí, circumstàncies que el portaven a sol-licitar del Capítol que li assenyalés mitja part del que cobraven els de la Capella, fins que es fes mereixedor de la paga sencera. El Capítol ho cometé al Sr. Protector de la Música. ${ }^{135}$

L'acta capitular que ara comentaré, li afegeix el nom de "Josep". Correspon al dia 3 de setembre de 1764 i diu que "Josep Miquel Prats", músic, demanava la futura de la primera plaça vacant de violí, a la qual súplica el Capítol respongué que no tenia lloc, encara que, com acabem de veure més amunt, ja tocava aquest instrument a la Capella. ${ }^{136}$

Josep PRATS. No sé per què, tinc el presentiment que aquest Josep Prats és el mateix Josep Miquel Prat/Prats, per ser tan contemporanis i demanant el mateix, però, donat que els documents que li fan referència, tot demanant precisament el mateix $\mathrm{i}$ amb les mateixes solucions, la diferència de data em duu a tractar-lo per separat. Efectivament, el 12 de novembre de 1763, el Mestre comunicà al Capítol que aquest escolà havia perdut la veu i sol-licitava per a ell la caritat acostumada. El Capítol resolgué que li donessin el que era costum i deixà la realització a mans del Sr. Protector. ${ }^{137} \mathrm{I}$, el 13 de juliol del 1764, el propi Prats presentà un Memorial, per mans del canonge Joan Alòs, demanant mitja part de la Capella, en la primera vacant de violí, a la qual petició respongué el Capítol dient que no tenia lloc, donat que no hi havia cap vacant de violí. ${ }^{138}$

N. N. Encara que no es doni el nom, no seria improbable que es tractés de Miquel Prat, el qual no rebé el vestit complet tot alhora. El canonge Jaume Roldós abonà, el 26 de novembre de 1763, 1 lliura i 16 sous, per tres parells de mitges d'estam de [?]; 9 sous per un parell de mida de dona; i 1 lliura per un parell a tres fils, les quals mitges eren per a un escolà que havia acabat la veu. En total, eren: 3 lliures i 5 sous. Les cobrà el canonge Joseph Vinyes, per Josepha Vinyes viuda, la qual devia ser cunyada del canonge, donat que les dones prenien el cognom del marit. ${ }^{139}$

Thomas PRESAS. El 15 d'octubre de 1764, Josep Pujol, Clergue i Mestre de Capella, exposà que aquest escolà havia acabat la veu i demanava per a ell la caritat acostumada, petició que fou avalada pel Capítol i comesa al Sr. Protector dels Escolans. ${ }^{140}$

\section{Escolans de cota morada}

Queixes. Acomiadament. Tot dóna a entendre que els escolans morats captaven a les portes de la Catedral, després dels sermons de la Quaresma, encara que no consta el motiu. L'acta que ara comentaré, del 22 de març de 1762, posa de relleu, a més, que alguns d'aquests escolans eren infidels -s'amagaven diners?- i foren acomiadats. Aleshores, alguns Beneficiats s'oferiren ells per fer la capta, però el Capítol els digué que aquesta novetat podria causar sorpresa i preferia que captessin aquells escolans, dels qui es tingués més seguretat. ${ }^{141}$

133. SIV. 24, f. $142 \mathrm{v}$.

134. AE, $1760-1761$, f. 11.

135. SIV. 24 , f. 209v.

136. SIV. 24 , f. $218 \mathrm{v}$.

137. SIV. 24, f. 180v.

138. SIV. 24, f. 211.

139. AE, $1763-1764$, f. 11.

140. SIV. 24, f. 224.

141. SIV. 24 , f. 70 . 
Llàntia. Segons l'acta capitular del 16 de setembre de 1763, els escolans morats havien comprat una llàntia per al seu altar que era el $\mathrm{N}^{\mathrm{a}}$. $\mathrm{S}^{\mathrm{a}}$. del Patrocini, la qual llàntia els havia costat set lliures, però que només en tenien quatre i encara ho treien del que ells guanyaven. El canonge Vinyes proposà que el Capítol podria pagar les lliures restants, però el Capítol resolgué que el propi canonge Vinyes, Caritater, pagués l'import sencer de les set lliures. ${ }^{142}$

\section{Entonador}

Entonadors. Falten al cor. El 14 de maig de 1756, el Capítol es lamentava que, malgrat ésser cinc, aleshores, els Entonadors, feien falta molt freqüentment a Matines i, a més, s'observava alguna oposició entre ells i es prengué l'acord capitular de que el Vicari General els amonestés, pel que feia a l'assistència al Cor, unió entre ells i bona armonia en portar el Cor"143

Entonadors. Ser posats en llista. Els entonadors demanaren al Capítol, d'acord amb l'acta capitular del 10 de novembre de 1757, d'ésser inclosos, com a oficials, en la llista que tenia el Bolser, a fi i efecte de participar en les distribucions de les visites que venien a la Catedral i en els Aniversaris particulars d'aquesta Seu, petició que el Capítol atengué i concedí, nivellant-los als altres oficials. ${ }^{144}$

Entonadors Clergues. L'acta capitular del 28 de maig de 1762, prén resolució, pel que fa a la circumstància d'haver de cantar les lletanies els entonadors "clergues", donat que els escolans de cota de grana, a qui corresponia fer-ho, estaven indisposats. Ho farien, doncs, els susdits entonadors, però amb almusa i no amb capa. ${ }^{145}$

Entonadors moderns. Encara malalts els Escolans de grana, es disposà que els quatre entonadors "moderns (!)", cantarien les quatre profecies que cantaven els Escolans, el dissabte següent a la data de l'acta. També es demanà que es prenguessin les degudes mesures, quant a la roba dels escolans que, pel que sembla, usaven indiscriminadament i podia ser la causa del contagi entre ells, així com també, que el Rnt. Presas, avi d'un dels escolans, es volia endur el seu net a casa, perquè fes millor la convalescència, a la qual decisió s'hi oposà el canonge Orteu, per orde del Capítol. Tanmateix, la resolució capitular diu que fou donada la llicència a Presas, perquè s'endugués el net a casa, a condició que, quan el Capítol el reclamés, el tornés a casa del Mestre. ${ }^{146}$

\section{Noms d'Entonadors}

Pere Joan / Pere Anton / Anton MONLLEÓ. Pel que fa a un Anton Monlleó que aparegué en un treball meu anterior (v. AnM, 56, CSIC, Barcelona, 2001, pg. 150, i a continuació d'aquest, un tal Pere Anton N., ambdós destacats per la seva preparació musical, el segon, fins i tot, s'oposà al magisteri de Figueres, voldria hipotetitzar i, fins i tot, establir com a tesi, sobre la identitat dels dos, això és, no són dos, sinó un de sol. I a més, per les dades que oferiré tot seguit, identificar-lo amb el "Pere Antoni Monlleó" que fou mestre de Capella de Sta. Maria del Mar. Les dades, com demostraré tot seguit, coincideixen plenament. Només hi ha, però,

142. SIV.24, f. $170 \mathrm{v}$.

143. SIV. 22 , f. 137.

144. SIV. 23, f. 62.

145. SIV. 24, f. 85.

146. SIV. 24 , f. 85. 
una petita dificultat i és la del nom. Però això només és aparentment per a mi, perquè ja m'ha ocurregut més vegades, en les meves recerques i en aquest mateix treball, que una mateixa persona aparegui designada amb diferents noms. I, en aquest cas, tenim: Pere Anton, Pere Joan i Anton. Però això deixa de ser un obstacle, si admetem que, aleshores, tothom tenia tres noms i podien designar-lo amb tots tres, o amb qualsevol d'ells.

En la narració biogràfica, procediré cronològicament.

En conseqüència, parlant d'una sola persona, resulta que l'entonador Pere Anton Monlleó, demanà llicència d'un mes, el dia 23 d'agost de 1756, per tal d'anar a veure sos pares, llicència que el Capítol li concedí de bon grat. Crida l'atenció, però, el detall que recull l'acta, pel que fa a la distància del lloc on vivien els seus pares, respecte de Barcelona. Diu que "distan tres dias de esta Ciutat". Això fa pensar que havia pogut náixer fora de Barcelona, però, només amb aquesta dada, sembla impossible establir el lloc del seu naixement. ${ }^{147}$ El 5 de desembre de 1757, va exposar al Capítol que feia vuit anys que servia els oficis d'entonador i de Contrabaix de la Capella i, puix que desitjava ordenar-se i no tenia títol eclesiàstic per fer-ho (enteneu: algun benifet per viure), demanà al Capítol que el perpetués en l'ofici d'entonador, a la qual petició accedí el Capítol, anotant que es fés "per lo modo, ab q.e se deu fer dita Perpetuisació". I va nomenar comissionats al succentor Vilar i al canonge Marquet. ${ }^{148}$ Una setmana després, això és, el 12 de desembre, aquests comissionats, exposaren ja al Capítol les condicions que consideraven bones per tal de perpetuar Monlleó. Opinaven que li podrien assignar 7 sous cada dia "per via de Distribució", opinió que també féu seva el Capítol, el qual cridà el notari, perquè n'aixequés acta, a partir del dia 5 , en què es prengué l'acord de perpetuar Monlleó. ${ }^{149} \mathrm{Hom}$ llegeix a l'acta capitular del 9 de maig de 1759, que el Capítol donà llicència i presència a Anton Monlleó, entonador, per anar a Tarragona "pera prendre la primera Tonsura". ${ }^{150}$

I, arribats en aquest punt, tenim que, segons mn. Baldelló, a Santa Maria del Mar, hi hagué un Mestre de Capella, conegut com Pedro Antonio Monlleó, el qual "se posesionó del magisterio el I ${ }^{\circ}$ de julio de 1759" i, a la Catedral, hom llegeix, a l'acta del primer de juliol de 1759 (data coincident amb la de mn. Baldelló), diumenge, que Pere Joan Monlleó Entonador es elegit M.e de Capella de S.ta Maria del Mar". Però, a la del 4 de juliol, dimecres, Pere Anton Monlleó, Entonador de la p.nt Iglesia amb Súplica féu present la seva promoció al Magisteri de Capella de Santa Maria del Mar per los Obrers de aquella Parroquia i suplicava al M. I. Capítol tingués a bé l'acceptacio de dit Magisteri'. I, a la del 29 d'abril de 1763, quan pensaren perpetuar l'entonador Miquel Vendrell, s'aconsellà que és fés com quan es va perpetuar "Mn. Anton Monlleó, M.e actual de la Capella de S.ta María del Mar". A l'acta de l'1 de juliol, es llegeix encara que, Pere Joan Monlleó havent d'exercir son nou ofici i no tenint temps per acomiadar-se, demanà permís per anar a exercir-lo, permís que el Capítol li concedí. ${ }^{151}$

Amb aquestes notícies, doncs, crec que es fa una aportació considerable al coneixement biogràfic que hom tenia d'aquest compositor, malgrat que encara resten descongudes altres notícies de la seva vida i formació.

Josep GOMES / GOMIS / GOMEZ. El 19 de novembre de 1756, aquest entonador presentà una Súplica al Capítol, si ens atenem a l'acta capitular d'aqueix dia, amb què feia present al Capítol els nou anys que servia aquest ofici, amb el salari de 50 lliures, més 7 sous diaris de distribucions i que, donat que tenia la seva mare vídua i pobre i ell es trobava de 30 anys i, a más volia ser promogut als Ordes Sagrats, demanava que el perpetuessin en l'esmentat ofici. El Capítol cometé la Súplica als comissionats d'entonadors, això és, el Succentor Vilar i els Srs. Bessa i Marquet, canonges. ${ }^{152}$ Aquests Srs. comissionats, no presentaren el resultat de la seva

147. SIV. 22 , f. 161

148. SIV. 23 , f. $64 \mathrm{v}$.

149. SIV. 23, f, 66v.

150. SIV. 23, f.137v.

151. Baldelló, Fc. de Paula, "La música en la Basílica Parroquial de Santa María del Mar, de Barcelona, AnM, XVII, CSIC, Barcelona, 1962; SIV. 23, f. 144 i SIV. 24, f. 144.

152. SIV. 22, f. 175.

94

Anuario Musical, 60 (2005)

(c) Consejo Superior de Investigaciones Científicas

Licencia Creative Commons 3.0 España (by-nc) 
gestió fins al dia 18 de juliol de l'any següent, amb la intenció de "veurer -com diu l'acta capitular-, si continuaría en recapasitar la Grammatica, y moderarse en son porte, modal, y Atenció, q.e apar ho cumpla; y en quant al Chor se ha moderát molt". Atenent, doncs, a aquesta millora, el Capítol resolgué perpetuar-lo, quant a les distribucions que passava de la Còngrua necessària, però no quant al salari. El notari capitular n'aixecà acta. ${ }^{153}$

El 20 de juny de 1760, hom troba una referència a alguna absència del cor, d'aquest entonador, de la qual presentava la fe de metge, acreditant que no havia residit, "infirmitatis causa", justificant que el Capítol admete. ${ }^{154}$

Aquesta vegada, la referència a Gómez està relacionada amb el cant de la Passió. Es troba a l'acta capitular del 12 d'abril de 1764. Els canonges Marquet i també Orteu recordaren que, puix que Andreu Torrents s'havia ordenat precisament per cantar els Passios, cantaria el del diumenge (enteneu: de Rams), mentre que el del dimarts el probaria Gómez i, si ho fés bé, podria cantar també el del divendres Sant. I així ho acordà el Capítol. ${ }^{155}$

El canonge Nadal manifestà al Capítol, el 10 de desembre de 1764, que, aquell matí Josep Gómez havia comès una falta - no diu quina- $\mathrm{i}$, per això, l'havia privat dels guanys de matines, sanció que aprobà el Capítol. També es va comentar que uns dies abans, l'entonador Josep CALDES "havía tingut mal modo â Mn Andreu Torrents Entonador" i el Capítol recomanà al canonge "Antiquior" que, si no cumplien, els castigués. ${ }^{156}$

Josep FIOLA. El Secretari capitular comentà, en la sessió capitular del 7 de maig de 1759, que havia rebut una carta de mn. Josep Fiola, entonador, el qual demanava d'ésser admès en les mateixes condicions que els entonadors del Cor de la Catedral de Barcelona. El Capítol li respongué "Que no té lloch". ${ }^{157}$

Un aragonès. L'acta capitular del primer de juny de 1759, el canonge Nadal manifestà al Capítol que hi havia un Entonador aragonès disposat a servir en aquest ofici i estava disposat a ser examinat de veu i de cant. Es resolgué que el Mestre de Capella l'examinés privadament i n'informés al Sr. Nadal, el qual n'informaria després al Capítol. ${ }^{158}$

Andreu TORRENTS. El 4 de febrer de 1760, es comunicà al Capítol que hi havia un entonador, anomenat Andreu Torrents, el qual havia servit en aquest ofici a la Catedral d'Urgell, "ab los guañables de 200 liures", i que, al present desitjava servir aquesta Catedral de Barcelona, "proporcionantli conveniencia". El Capítol li respongue que, aleshores, no era possible. ${ }^{159}$ Tanmateix, altra acta, de dos anys després, això és, de l'11 de març de 1762, torna a parlar de la pretensió d'en Torrents, del qual diu que era Clergue, que tenia "veu de Contrabaix", que havia regit el Cor de la Catedral d'Urgell durant 5 anys -"de ahont se retirá per falta de saber"-, que aleshores servia a Santa Maria del Mar i que, trobant-se amb suficiència per servir el d'aquesta Catedral de Barcelona i formar part de la seva Capella de Música, demanava ésser admès amb una còngrua conveniència. El Capítol cometè aquesta súplica als canonges Sr. Marquet i Sr. Orteu, perquè l'estudiessin, així com la d'altres pretendents a l'ofici de contrabaix. ${ }^{160}$ Quinze dies després, això és, del 29 de març de 1762, l'acta capitular diu que el Sr. Marquet i el Sr. Orteu, canonges, havien fet examinar l'esmentat Andreu Torrents, "pretés Entonador" i, a més, se n'havien informat per altres costats i havien conclòs que seria molt útil per al servei de la Catedral. En aquesta ocasió, doncs, fou admès, però es recomanà encara a Marquet $i$ a Orteu que esbrinessin quines eren les seves pretensions. ${ }^{161}$ Ambdós canonges informaren, el primer d'abril immediatament següent, que havien ajustat amb en Torrents els guanys que tindria i serien: 25 lliures de salari i 60 lliures que li produïria la Capella de Música, pretensions que li valgueren l'admissió i l'aprobació del salari. ${ }^{162}$

153. SIV. 23 , f. 49.

154. SIV. 23, f. 193v.

155. SIV. 24 , f. 199.

156. SIV. 24 , f. 231.

157. SIV. 23, f. $137 \mathrm{v}$

158. SIV. 23 , f. $140 \mathrm{v}$.

159. SIV. 23 , f. $173 \mathrm{v}$.

160. SIV. 24, f. 68.

161. SIV. 24, f. 72

162. SIV. 24, f. $72 \mathrm{v}$. 
En ocasió de l'òbit de l'entonador Mateu Blanc, qui cantava els "Passios", el canonge Mateu féu present, el 14 d'octubre de 1763, els mèrits de Torrents, pel tal d'ésser perpetuat. Adduí, doncs, que cap dels entonadors ordinats no podia cantar el Passio i que, essent l'entonador Torrents molt bo, de bona veu i de molt bons costums, si el perpetuessin, podria ordenar-se i així, la propera Setmana Santa ja podria cantar el Passio. A més, a més, segons informacions que Marquet havia rebut, Torrents havia tingut molta consideració i veneració al Capítol, ja que, havent-lo instat amb bones conveniències, des d'una altra església, preferí la Catedral. I d'això també en donà testimoni el canonge Antonino Sentmenat. En conseqüència, el Capítol el perpetuà, en les mateixes condicions que ho feia amb els altres, de la qual decisió en prengué acta el notari. ${ }^{163}$

Els canonges Sr. Marquét i Sr. Orteu feren present, el 12 d'abril de 1764, que, donat que Torrents s'havia ordenat per tal de cantar els Passios, ell podria cantar el del diumenge -enteneu de Rams-i Josep Gómez el del dimarts -Sant-. El Capítol acceptà el suggeriment i, a més, afegí que, si el susdit Gómez ho fes bé, podria cantar també el del divendres -Sant-. ${ }^{164}$

A l'acta capitular del 22 de març de 1764, hom llegeix que el Sr. Sentmenat i el Sr. Marquet manifestaren al Capítol que, la perpetuitat de l'entonador Torrents i la seva ordenació immediata, per cantar els Passios, li havien suposat despeses especials i, per això, demanava alguna caritat. El Capítol li concedí 30 lliures i en féu manament. ${ }^{165}$ pares. $^{166}$

El dia 27 d'agost de 1764, demanà llicència de tres setmanes i li fou concedida, per anar a veure els seus

El 20 de desembre de 1765, Torrents presentà una súplica al Capítol, tot demanant augment de salari, ja que el que tenia no excedia les 25 lliures. El Capítol comissionà els canonges Basteró major, Marquet i també Orteu. ${ }^{167}$

Entonador d'Esparreguera. A l'acta capitular de l'11 de febrer de 1765, consta que el Sr. Marquet i el Sr. Orteu, informaren al Capítol, referent a un entonador d'Esparreguera, del qual s'omet el nom, com en altres ocasions semblants i per raó de no perjudicar l'interessat, el qual probablement ja actuava en altra església. Aquests senyors, manifestaren que, dies passats, havia passat per la Seu un entonador d'Esparreguera, al qual examinaren, tot fent-lo cantar al Cor i asseguraven que la veu era molt bona i bastant abultada, que era molt pràctic de solfa i que, a més, el van tantejar sobre quedar-se i ell, havent obtingut el consentiment del seu pare, digué que sí; que també s'informaren de les seves pretensions i comprovaren que eren inferiors a les que tenia l'entonador Miquel Vendrell. També n'havien parlat amb el Mestre de Capella, el qual digué que el considerava molt i que, tenint-ne necessitat la Capella, s'inclinaven perquè fos admès. Es resolgué que el fessin venir, per tal que l'escoltessin els Srs. Capitulars i fos examinat, després de completes, en el Cor. ${ }^{168}$

Miquel VENDRELL. El canonge Marquet féu present al Capítol, com consta de l'acta capitular del dia 16 de desembre de 1757, que l'entonador Miquel Vendrell desitjava entrar en la infermeria de la Capella de Música que s'havia creat. I, encara que ell, per orde del M. I. Capítol, només participava en les actuacions de la Capella dins de la Catedral, i això li permetia pagar la quota d'ingrès que comportava 5 lliures, en sol-licitava l'exenció. Juntament amb aquesta petició, el canonge Marquet presentà també el compte de les despeses hagudes amb l'esmentat Vendrell, les quals despeses arribaven a 80 lliures i necessitava d'un Manament. El Capítol resolgué d'admetre Vendrell a la infermeria, i pagar les 80 lliures, a les quals s'haurien de sumar les 5 lliures de la quota que hauria hagut de pagar. El Notari capitular en prengué "la paraula". ${ }^{169}$

163. SIV. 24 , f. $176 \mathrm{v}$.

164. SIV. 24, f. 196.

165. SIV. 24, f. 196v.

166. SIV. 24 , f. $217 \mathrm{v}$.

167. SIV. 24, f. 291.

168. SIV. 24 , f. 241 .

169. SIV. 23 , f. $67 \mathrm{v}$.

96

(c) Consejo Superior de Investigaciones Científicas Licencia Creative Commons 3.0 España (by-nc)
Anuario Musical, 60 (2005)

http://anuariomusical.revistas.csic.es 
El 26 de juny de 1758, el canonge Marquet exposà al Capítol que l'entonador Vendrell, qui s'hostejava a casa del Mestre de Capella, es quiexava al Capítol de la incomoditat del llit, en què dormia i suplicava que el Capítol manés fer-ne un de nou. El Capítol ho deixà a mans del propi canonge Marquet. ${ }^{170}$

L'acta capitular del 28 de maig de 1759, es fa ressò d'una súplica de Vendrell, amb què manifestava al Capítol els més de sis anys que servia al Capítol, a canvi del menjar, calsar i vestir i que tenint mare viuda i pobra, no la podia socórrer en aitals condicions. En conseqüència, demanava alguna conveniència. El Capítol encarregà la solució al Succentor Vilar i a Marquet. ${ }^{171}$ Un mes després, aproximadament, això és, el 25 de juny del susdit any, aquests Srs. presentaren al Capítol el Memorial de Miquel Vendrell Entonador i proposaren que li assignessin 180 lliures anuals, segons els conceptes següents: 40 lliures de salari i les restants a títol de distribucions, proposta que fou aprobada pel Capítol. ${ }^{172}$

El Mestre de Capella, trobant-se mancat de veus de Contrabaix, per a les funcions de fora de la Catedral, demanà permís al Capítol, el dia 11 de juliol de 1759, per tal de poder incorparar-hi Vendrell, el qual lucraria també la part corresponent. El Capítol cometé la petició al Protector de la Capella. ${ }^{173}$ La informació la donà, el dia 13 dels susdits mes i any, el canonge Vinyes, "en nom de son Principal lo S.or D.n Pau Dalmases" i el Capítol donà la corresponent llicència, perquè l'entonador Miquel Vendrell participés en les funcions de la Capella, fora de la Catedral. ${ }^{174}$

En un Parlament extraordinari, després de Completes del diumenge 14 d'octubre de 1759, presidit pel Sr. Anton Rius, el canonge Vinyes manifestà que Miquel N. (Vendrell?) Entonador, li havia dit que el Mestre del Palau, de part del Sr. "Vice-Patriarca", li havia enviat un missatge, perquè comparegués, el dia següent, a les sis de la tarda, a casa del Mestre, per probar alguna obra que s'havia de cantar en les funcions de Sa Majestat, després que arribés a Barcelona. El Capítol, considerant que no s'havia de fer cas del Mestre del Palau i que la pròpia Catedral necessitaria de tots els seus músics, resolgué que cap dels seus Cantors o Músics, no assistissin al Mestre del Palau i que el Mestre de Capella de la Catedral fes la proba dels papers que tenia preparats i que el susdit Miquel digués al Mestre del Palau que estava ocupat a la Catedral. ${ }^{175} \mathrm{Al}$ dia següent, 15 d'octubre de 1759, el canonge Josep Riera insistí que un músic, sense dir cap nom, li havia participat també que havia rebut un missatge del Mestre del Palau, perquè assistís a la proba d'uns papers que havien de cantar-se a Santa Maria, en les funcions que s'hi havia de celebrar, en ocasió de la vinguda de Sa Magestat. La resposta del Capítol fou: que aquest músic s'estés a les ordes del Sr. Protector de la Capella. ${ }^{176}$

El 21 de gener de 1760, Vendrell, mitjançant Súplica, demanà al Capítol certificat dels vuit anys discorreguts, d'ençà que el servia i que fos redactat en la forma acostumada. El Capítol resolgué que es fes, com ho demanava l'interessat. És desconegut, per ara, el motiu d'aquest certificat. ${ }^{177}$

El 13 de març de 1761, li fou concedida llicència per absentar-se alguns dies de Barcelona. ${ }^{178}$ Aquesta mateixa petició d'absentar-se uns dies, la repetí diferents vegades, per exemple, el dia 5 d'octubre de 1761 i el 10 de maig de 1762 , ocasions en què també demanà la presència. La del 5 d'octubre fou comesa al canonge Marquet i la següent li fou concedida immediatament. ${ }^{179}$

L'acta capitular del 15 d'abril de 1763, recull la petició de Miquel Vendrell, entonador, amb què recordava els 10 anys de servei a la Catedral i que, trobant-se de 28 anys, desitjava ésser promogut a l'estat

170. SIV. 23, f. $98 \mathrm{v}$.

171. SIV. 23 , f. $139 \mathrm{v}$.

172. SIV. 23 , f. $143 \mathrm{v}$.

173. SIV. 23 , f. $145 v$.

174. SIV. 23 , f. 146.

175. SIV. 23, f. 160.

176. SIV. 23 , f. $160 \mathrm{v}$.

177. SIV. 23, f. $171 \mathrm{v}$.

178. SIV. 24 , f. $19 \mathrm{v}$.

179. SIV. 24 , ff. $47,79$. 
sacerdotal, però no tenia títols per a poder-se ordenar i, per això, demanava ésser perpetuat, amb l'assignació d'una còngrua suficient, gràcia que li fou concedida i es delegà l'execució en el canonge Marquet. ${ }^{180}$ La corresponent acta del 29 dels mateixos mes i any, aconsellà i es prengué la resolució de fer-ho, com es féu en la perpetuació de Mn. Anton Monlleó, que passà a Mestre de la Capella de Santa Maria del Mar" i consistia en set sous diaris. ${ }^{181}$

Entonador nou. De moment, no tinc idea de qui es tracta i, en conseqüència, no m'atreveixo a formular cap hipòtesi. El cert és que el dia 28 de febrer de 1765, "hora $2^{a}$ vespertina", els canonges Sr. Marquet i Sr. Orteu, feren present al Capítol, després d'haver oït tots l'entonador nou que s'havia examinat, que, aquest demanava el mateix que Miquel Vendrell, amb la sola diferència del salari, diferència que no s'expressa. El Capítol l'admeté en les condicions proposades pels Srs. Comissionats i el Notari en llevà acta. ${ }^{182}$

Josep PRAT /PRATS. Sense cap mena de dubte, es tracta de l'escolà de cota de grana que acabà la veu dos anys abans. Com en altres ocasions, també trobem alguna alternància en el seu cognom, Prat / Prats. I, pel que fa a l'ofici que tenia a la Catedral, en aquest document se'l defineix com a dormitorer i com a entonador. En els documents següents, però, sempre es parla d'ell com a entonador.

Efectivament, hom llegeix a l'acta capitular del 22 d'abril de 1765, que Josep Prat, dormitorer, havia presentat una Súplica al Capítol, demanant el salari proporcionat al mèrit que li assistia i les mateixes distribucions que rebien els altres entonadors. I deia que el movia a fer-ho el fet de ser l'antiquior dels entonadors, ja que en prengué possessió l'any 1733 i actualment era d'edat de 63 anys, quan més necessitava d'aquesta subvenció. El Capítol delegà la Súplica en els canonges entonadors, Sr, Marquet i Sr. Orteu. ${ }^{183}$ Aquests Srs. feren relació del Memorial de Prats, al qual també es coneixia per l'àlias de "Caldas", "on tenia el seu títol", segons publicació meva anterior, el 6 de maig del mateix any 1765 i es manifestaren partidaris d'augmentar-li les distribucions fins a equiparar-lo als demés entonadors, opció que aprobà el Capítol. ${ }^{184}$

Josep SALA. Aquest entonador, en Súplica llegida al Capítol, feia constar, el dia 4 de novembre de 1765, que havia practicat durant dos anys com a succentor del Cor de la parròquia de Sant Jaume de la present Ciutat i manifestava que seguia la Capella de Música amb la illlusió de ser admès al Cor, sense cap pretensió de distribucions, ni de perjudicar els altres entonadors, però confiant que li concedirien vestir els hàbits corresponents, així com també un lloc corresponent al Cor. Aquesta petició fou comesa als Srs. Sagristans Majors. ${ }^{185}$ Aquests Srs. feren relació de la comissió rebuda, pel que feia al Memorial del clergue Josep Sala, el 25 de novembre de 1765 , tot dient que, després d'haver-se informat responsablement, podien dir de Sala, que era de molt bona veu, encara que no era massa pràctic de solfa, però que l'estudiava i que sabia "tal qual de llegir". Quant a la resta, si el Capítol el volia admetre sense salari, com el mateix Sala proposava, podria ésser admès com a oficial, per tal de poder vestir hàbits. El Capítol resolgué, finalment, que fos admès, en les condicions proposades per l'interessat, el 4 de novembre corrent i entrà el Notari, per llevar-ne acta. ${ }^{186}$

Francesc ARDERIU. Demanà amb Súplica que arribà a capítol, el 8 de novembre de 1765, d'ésser admès com entonador, amb el salari i distribucions ben vistes al Capítol per a mantenir-se, el qual li respongué que no tenia lloc la petició. ${ }^{187}$

Mateu, BLANCH. Possiblement germà de Tomàs Blanch. Ja el coneixiem, però el document que segueix ens mostra una faceta que ens sobta i el Capítol pretén ajudar-lo a sortir-ne. El 14 de maig de 1756, demanà una gratificació i que li posessin el salari com el de l'entonador Gomes, adduïnt "q.e ab los 7 sous coti-

180. SIV. 24, f. 142 .

181. SIV. 24 , f. 144

182. SIV. 24 , f. 242.

183. SIV.24, f, 249v.

184. SIV. 24 , f. $252 \mathrm{v}$

185. SIV. 24 , f. $281 \mathrm{v}$.

186. SIV. 24 , f. $285 \mathrm{v}$.

187. SIV. 24 , f. 283 
dians de distribució no pot viurer ab la decencia, q.e li correspon, a mes q.e encara, q.e sia Beneficiat, es poca cosa lo q.e trau de St. Sever, y de Misas no mes, q.e 20 mensuals". El Capítol li concedí, "pro hac vice", 25 lliures, "per satisfér alguns deutes del referit Matheu Blanch", les quals lliures li pagaria el canonge caritater Font, "qui procurará â persuadir (enteneu: Blanch) de la afició al joch, en q.e consum los emoluments, q.e percebeix; q.e junts no son tan modichs, com ell pondera; q.e procuria regularse, q.e may mes recorria ab semblants suplicas." 188

A petició del propi Blanc, el Capítol li concedí llicència i presència (només en els ploms, el 30 de juliol de 1756, per anar un mes a "sa Patria" i, a més, li anticiparen el salari d'un mes, però l'advertiren que, si no complia millor la seva obligació, quan regresaria, no li concedirien més la presència. ${ }^{189}$

El 16 de març de 1758, recordà al Capítol la gràcia que li feren uns anys abans, de 25 lliures i, trobantse novament en necessitat, demanava la gràcia ben vista al Capítol, el qual passà la Súplica al canonge Font, perquè s'informés i li recomanà que hi donés llargues. ${ }^{190}$ Font féu relació d'aquesta comissió, el 7 d'abril de 1758, i digué que li podien donar 21 lliures, en atenció al seu bon comportament en la Setmana Santa i perquè realment ho necessitava per satisfer certs deutes, suggeriment que aprobà el Capítol. El Notari prengué la paraula. ${ }^{191}$

El 4 de setembre de 1758, li concediren llicència i presència “ more solito", per tal d'absentar-se un mes, per complir una prometença. ${ }^{192}$

El 6 de juny de 1759, demanà una subvenció "com acostuma ferli tots los Anys lo M. I. Cap.l”, petició que fou comesa al Sr. canonge Font. ${ }^{193}$ Aquesta mateixa petició, o semblant s'anirà repetint en anys següents. Així, doncs, el 21 d'abril de 1760, suplicava al Capítol que, a més dels 7 sous diaris, li fessin la mateixa gràcia que en anys anteriors, gràcia que li fou feta. ${ }^{194}$ Nova llicència i presència per anar quinze dies fora Ciutat, li concediren, atenent a una Suplica presentada el 31 d'agost de $1761 .{ }^{195}$

Altra gratificació demanà al Capítol, com les que li venia concedint des de l'any 1749 , com fa constar en la seva Súplica del dia 14 de maig de 1762. Aquesta vegada, però, la demanà "per via de salari" i fa constar que se li atorgava, en atenció a la seva aplicació i puntualitat en el servei. La Súplica fou comesa al Sr. Marquet i al Sr. Orteu. ${ }^{196}$ L'informe que presentaren aquests Srs. comissionats mogué a concedir-li 25 lliures, per via de salari ${ }^{197}$ El 9 d'agost de 1762, demanà quinze dies, i li foren concedides, com si fossin vacances ("recreat.s causa"), llicència i presència, per tal d'acompanyar un germà seu malalt a Ager. ${ }^{198}$

El 8 de setembre de 1763, hi hagué parlament especial en la sagristia, després de Completes, presidit pel canonge Nadal, en el qual s'informà de la gravetat de Mn. Mateu Blanc. Els infermers de Sant Sever havien dit que els metges eren del parer que s'havia de combregar, encara que no hi anava de dues hores. Que s'havia avisat el confessor del malalt, perquè ho fes saber al propi malalt $i$, si es considerava urgent, hi anirien aquella mateixa tarda, però s'ajornà per al dia segûent. ${ }^{199}$ L'òbit de Mateu Blanc s'esdevingué la nit del 18 al 19 de setembre del susdit any i aquell mateix matí del 19 es prengueren les mesures acostumades per fer l'absolta i el funeral i per tornejar la vacant. ${ }^{200}$

188. SIV. 22, f. 137.

189. SIV. 22 , f. $154 \mathrm{v}$.

190. SIV. 23, f. $78 \mathrm{v}$.

191. SIV. 23, f. $80 \mathrm{v}$.

192. SIV. 23 , f. $108 \mathrm{v}$

193. SIV. 23 , f. $140 \mathrm{v}$

194. SIV. 23, f. $183 \mathrm{v}$.

195. SIV. 24, f. 44.

196. SIV. 24, f. 80.

197. SIV. 24 , f. 84

198. SIV. 24 , f. $101 \mathrm{v}$.

199. SIV. 24 , f. $168 \mathrm{v}$.

200. SIV. 24 , f. 171. 


\title{
Contralts
}

Bernat CASADEMUNT. El divendres 16 de gener de 1756, Maria Casademunt, la seva vídua, demanà les rosses que percebia el seu marit difunt, Bernat Casademunt, "Musich de la Capella de V. S." [contralt, v. Agustí Siurach], "ô be la Caritat â V. S. Ben vista", tot exposant que, aquest, havia servit més de quaranta anys la Capella de música de la Catedral i que ella era "de crescuda edat, Pobre, y ab una filla donzella". Es passà la súplica al Protector de la Capella de música ${ }^{201}$. Aquest informà al Capítol, el divendres 30 dels mateixos mes $\mathrm{i}$ any, dient que el contingut de la petició presentada per la vídua Casademunt era veritat i que la considerava "digna de alguna comisseració" i es prengué l'acord de donar-li de per vida una rossa la qual li pagaria el Caritater ${ }^{202}$. El 23 de febrer de 1756, es fa constar que la plaça de contralt era vacant per mort de Bernat Casademunt ${ }^{203}$.

Agustí SIURACH. Coneguda la vacant de contralt, produïda per òbit de Bernat Casademunt, Siurach la demanà al Capítol, el dia 23 de febrer de 1756, adduïnt a favor seu els molts anys de servei del seu pare Joan Ciurach/Siurach, com a primer oboè de la Capella i també els quatre anys que ell mateix l'havia servida i oferint-se a tocar el violí sempre que calgués. Aquesta súplica fou comesa al Protector de la Capella ${ }^{204}$. La informació, en canvi, la donà el Protector dels Escolans, el dilluns 22 de març del susdit any i el Capítol resolgué que no tenia $110 c{ }^{205}$

Aspirants a contralt: Josep SEREÑANA, Clergue, y Mestre de Capella, q.e fou de S.ta Coloma de Queralt; Joan CASANOVAS, primer contralt de la Capella de Santa Maria del Mar de la present Ciutat, escolà de grana, que fou del M. I. Capítol; Llorens MARSAL, Arpista de la Capella del Palau; i Agustí CIURACH Musich de la Capella de la present església, amb llurs Súpliques, respectivament, presentades al Capítol, el dia 8 d'agost de 1757, demanaven, cadascú a favor seu, la plaça de contralt, vacant per promoció de Manuel Planas, darrer obtentor, a Arxillaút. El Capítol ho cometé al Protector de la Capella. ${ }^{206}$ Uns dies després dels quatre anteriors, el 19 d'agost de 1757, Joan BERNADÉT també demanava la mateixa plaça vacant de contralt, súplica que també fou comesa al Protector de la Capella. El canonge Anton Rius féu present que seria convenient oir els pretensors a l'ofici de contralt. ${ }^{207} \mathrm{El} 22$ d'agost i, pel que sembla, després d'haver oït tots els pretendents, el Sr. Albert Ibarra en féu relació al Capítol -l'acta diu que la féu "dels Pretensors als Oficis de de Contralt, y SotaContralt de la Capella"-, el qual Capítol decidí que fos admès Llorenç Marsal i que es continués donant la part de la Capella a Ambrós Coromines i encarregà novament a Ibarra que mirés de trobar un altre contralt. ${ }^{208}$

Anton VILLAR. És l'altre contralt que el Capítol demanà a Ibarra, com s'ha vist en l'admissió de Llorenç Marsal. Tanmateix la presentació la féu el canonge Font, en absència d'Ibarra. En efecte, el divendres 30 de setembre de 1757, Font digué que Villar era clergue i contralt de Lleida, el qual pretenia ocupar la plaça de contralt en aquesta Seu i que el Capítol ja havia comprobat, els darrers dies, que la seva veu era molt bona $\mathrm{i}$ també l'estil. Que altres informacions l'avalaven com a subjecte de bons costums i que a Lleida tenia la conveniència d'unes 200 liures i que pel mateix preu, es quedaria açí. El Capítol l'admeté, fent-li una conveniència semblant a la que tenia a Lleida, això és, 60 lliures de salari, com a part de la Capella, més la meitat de les matinals i siestes i els altres guanyables de la Capella. ${ }^{209} \mathrm{El}$ seu nomenament, com a oficial del Capítol, és del divendres 7 d'octubre del mateix any. El Notari n'aixecà acta. ${ }^{210}$

\author{
201. SIV. 22 , f. $114 \mathrm{v}$. \\ 202. SIV. 22,116 \\ 203. SIV. 22 , f. $120 \mathrm{v}$. \\ 204. SIV. 22, f. 120v. \\ 205. SIV. 22, f. 123. \\ 206. SIV. 23, f. 53. \\ 207. SIV. 23, f. 54 \\ 208. SIV. 23, f. 54. \\ 209. SIV. 23 , f. 58. \\ 210. SIV. 23, f. 59v.
}


El 2 de març de 1758, demanà l'admissió al Cor, encara que només fos amb sobrepellís per tal de poder tenir franqueses ${ }^{211}$, ja que d'altra manera no ho havia pogut aconseguir i hi havia indicis d'haver-hi exemplars. El Capítol recomanà al Sr. Ibarra que mirés els susdits exemplars i en fés relació. ${ }^{212} \mathrm{El}$ Sr. Ibarra informà al Capítol, el 13 dels mateixos mes i any, del fet que havia trobat un exemplar d'un músic que entrava al Cor amb hàbits i sense cobrar les distribucions, com proposava l'Anton Villar i el Capítol l'admeté en les mateixes condicions. ${ }^{213}$

El 26 de setembre de 1760, demanà augment de salari, tot manifestant que les 190 lliures que rebia, no li abastaven per mantenir-se ell i la seva mare i afegí que, a la Catedral de Lleida, n'hi oferien 260. Ara bé, ell estava molt gustós de servir en aquesta Catedral de Barcelona, però esperava que li fessin una major conveniència, petició que fou comesa al canonge Vinyes. ${ }^{214}$ L'informe sobre aquest Memorial de Villar, el presentà l'esmentat canonge Vinyes, el 10 d'octubre del mateix any, dient que "â vista de q.e la veu del Sup.nt era unica", ell mateix havia proposat que, restant a Joan Feliu, primer contralt, la meitat de les siestes i dels matinals, aquest es quedaria igualment amb el salari que tenia. Entenc que era per donar aquests actes a Villar. El Capítol s'hi avingué, però deixà ben clar que, a Feliu, se l'havia de compensar de la meitat de les siestes i matinals, import que s'avaluà en 36 lliures. $^{215}$

El 24 de setembre de 1764, aquest contralt manifestà al Capítol que, en la Capella del Palau, li oferien millors conveniències i, si li ho autoritzessin, deixaria els hàbits clericals. El Capítol li respongué que anés a on li semblés més convenient. ${ }^{216}$

Tomàs BLANCH. El dimecres 7 de juny de 1758, el clergue i contralt, Tomàs Blanch, demanà ser admès per contralt de la Capella, amb el salari corresponent a la part de la Capella, tot al-legant que havia servit dit ofici durant tres anys sense cap mena d'interès i que Josep Presas, no podia servir aquest ofici. El Capítol cometé la Súplica al Sr. Protector de la Capella. ${ }^{217}$ El 14 següent dels mateixos mes i any, el Sr. Joan d'Alòs, exposà els motius, pels quals l'esmentada Súplica no s'havia de tenir en compte, i, en conseqüència, es resolgué que no tenia lloc. ${ }^{218}$ No consta en lloc que tingués algun parentiu amb Mateu Blanc, de qui he tractat més amunt, però crec que tampoc no es pot descartar.

Jaume BARTRA. En Súplica adreçada al Capítol de la Catedral, el 28 de setembre de 1764, li manifestà que havia estat escolà de cota de grana i aleshores, era clergue i contralt de la Capella del Palau, però que, assabentat de la vacant ocasionada per la partença del contralt de la Seu (enteneu: Anton Villar), demanava ésser admès com a tal, amb el salari "â V. S. ben vist". El Capítol ho cometé al Protector de la Capella. ${ }^{219}$

Ambrós COROMINES. El 4 de febrer de 1765, presentà una súplica al Capítol, amb què manifestava l'honor de servir la Capella de Música, en qualitat de segon contralt, des de feia alguns anys, fins i tot suplint el primer i sempre que el Mestre ho disposava, però que essent tan curta la part de la Capella, demanava al Capítol que es dignés assignar-li salari, però li respongueren que no tenia lloc allò que demanava. ${ }^{220}$

Contralt, de Solsona. L'acta capitular del 9 de novembre de 1764, presenta un altre pretenent a la vacant de contralt deixada per l'Anton Villar, el qual pretenent era de Solsona i el Sr. Joan Alòs digué que estava disposat a venir i ésser examinat, però reclamava algun ajut de costa per al viatge. El Capítol digué que no li donessin cap ajuda, però, si volia venir, el faria examinar. ${ }^{221}$

211. Pavia i Simó, J, "La Capella de Música de la Seu de Barcelona des de la mort de F. Valls (2-6-1747) fins a l'any 1755, pg. 133, <Músics "seculars", o "no clergues">.

212. SIV. 23, f. 77 .

213. SIV. 23, f. 78.

214. SIV. 23, f. 210.

215. SIV. 23, f. 212.

216. SIV. 24, f. $220 \mathrm{v}$.

217. SIV. 23, f. 94.

218. SIV. 23 , f. 95 .

219. SIV. 24 , f. 221.

220. SIV. 24, f. 239.

221. SIV. 24, f. 227. 
Ignasi LLOR. El canonge Basteró, Protector de la Capella, féu present al Capítol, el dia 27 de setembre de 1765, que, donat el temps que faltava contralt a la Capella, fins al punt que ja començaven a queixar-se de la falta els músics, el poble i les esglésies, on la Capella anava a cantar, n'havia probat dos que s'havien presentat recentment, en la funció del Sant Crist del Claustre, el 21 pròxim passat i un d'ells també a l'església de la Mercè, a on envià el susdit Basteró, un subjecte de tota la seva confiança, perquè, després d'oir-lo, l'informés. I havent-se informat també dels membres de la Capella, resultava que ni un, ni l'altre eren perfectament contralts, però que Ignasi Llor era millor i tenia molt bon estil i que podrien suplir la falta, si l'admetien. El Capítol donà les gràcies a Basteró i deixà a les seves mans l'admissió i el salari, a condició, però, que, si un dia aparegués altre contralt más hàbil, hi hagués possibilitat d'admetre'1. ${ }^{222}$ En el capítol següent del dia 30 dels susdits mes i any, Basteró informà al Capítol que Ignasi Llor podia ésser admès amb el salari de 40 lliures anuals, moció que el Capítol acceptà, concedint-li, però, les quaranta lliures "durante beneplacito". 223

\section{Tenors}

Francesc SALT i SALLENT. L'acta capitular del 26 de setembre de 1763, recull la petició de salari d'aquest tenor, el qual exposà que, d'edat de nou anys entrà com a escolà de cota de grana $i$, després, fou admès com a tenor de la Capella, sense rebrer cap mena de salari, salari que demanava en la forma que millor li semblés al Capítol i en la forma com el tenien els altres individus de la Capella. El Capítol acordà donar-li 20 lliures en atenció de sos mèrits. ${ }^{224}$

\section{Músics}

Musichs Seculars. El 30 d'abril de 1762, presentaren una súplica al Capítol, relacionada amb el favor que els suposava el privilegi de l'indivís i de les franqueses, les quals, d'acord amb el Memorial presentat pel Capítol, el 17 d'octubre de 1755, els les havien retirat i no s'havien pogut recuperar. Aquests músics, doncs, que no es podien mantenir amb el salari, com confessaren, proposaren al Capítol que els subvingués amb rosses, o altres subsidis que suplissin la manca de l'indivís que fruïen. Petició que fou comesa al Protector de la Capella. De les franqueses, n'he parlat més amunt, en donar les dades biogràfiques d'Anton Villar. ${ }^{225}$

\section{Noms de Músics}

Francesc RUEDA. El 13 d'agost de 1759, demanà salari al Capítol, pel fet que suplia al músic Josep Drument, malalt $\mathrm{i}$, a més a més, tenia alguns ròssecs. La seva súplica fou comesa al Sr. Protector de la Cape$1 l a{ }^{226}$ El Protector, canonge Vinyes, en la sessió capitular del 20 dels susdits mes i any, informà sobre aquest Memorial que li cometeren de Fc. Rueda i li encarregaren novament que esbrinés com i per quin títol percebia Josep Drument el salari del càrrec que aleshores servia el suplent. ${ }^{227}$

Manuel ALOY. El 29 de novembre de 1762, exposà, en una súplica al Capítol, que feia més de tres anys que servia la Capella de la Catedral i demanava que li assignessin part en la Capella, per tal d'alimentar-se ell i la seva mare. Fou comesa als canonges Sr. Tagell i Sr. Orteu. ${ }^{228}$

Jaume ROVIRA. Músic. El 28 de febrer del 1763, demanà la gràcia de lluisme, per la venda que volia fer d'una casa, al carrer de Jaume Giralt, en domini de la pabordia de gener, gràcia que el Capítol li concedí. ${ }^{229}$ 


\section{Llibres de Música.}

Llibres de Cor. Els entonadors manifestaren al Capítol, el 26 de juny de 1758, la necessitat que hi havia de compondre els llibres de música, en uns dels quals la lletra estava esborrada i en altres, "no poderse llegir per ser llemosina". En conseqüència, esperaven que es prengués la providència oportuna. I fou comesa als Srs. Obrers. ${ }^{230}$ Aquests Srs. n'informaren al Capítol, el 25 de setembre 1758 i el Capítol resolgué que es suspengués la composició dels llibres de Cor. ${ }^{231}$

\section{Copista}

Àngela MARTí. El canonge Marquet presentà, el dia 14 de maig de 1759, una Súplica d'Àngela Martí, vídua i llibretera de la present Ciutat, amb la qual recordava que el seu marit difunt, havia treballat, l'any 1754, en la composició dels llibres de l'Arxiu, com constava en el compte presentat. I, donat que ella, de sa part, devia algunes pensions de censals que desitjava satisfer, proposà al Capítol que son compte es compensés amb les susdites pensions. El Capítol ho cometé als Srs. Arxivers. ${ }^{232}$ En resposta, el canonge Marquet informà, el 3 d'agost del susdit any 1759, que Mauro Martí havia treballat, efectivament, en la composició dels llibres, però que no podia informar de l'import dels treballs i li encarregaren que ho compongués. ${ }^{233}$ Aquest Sr. informà novament, en la sessió capitular del 7 de setembre immediatament següent, que l'esmentada Martí condonaria 4 lliures i 10 sous i es donaria per compensada amb 32 lliures. Aixì fou aprobat i el Notari n'aixecà acta. ${ }^{234}$

\section{Examen de cant}

Amb el present apartat, queda patent l'interès de la Catedral per la dignitat del cant, la qual no afluixà, ni abandonà la proba de l'examen de cant per a tots els canonges i beneficiats que entraven en actiu i volien participar del benefici de les distribucions del que s'anomenava "la Bossa Comuna". Considerant, però, que més aviat es tracta d'un apartat testimonial, em limitaré a donar el nom i les dates de la petició de l'examen per a l'“admissió a les distribucions de la Bossa Comuna" i la realització d'aquest amb la conseqüent admissió, si consta. I posar de relleu, cas que consti, sobre què versà l'esmentat examen.

Josep Anton PERMAÑER. Va demanar l'admissió a les distribucions, el dilluns 12 de gener de 1756. Fou examinat i admès, el 16 de gener del susdit any ${ }^{235}$.

Valentí RIERA. Beneficiat. El 14 de juny de 1756, va demanar l'admissió. Fou examinat "de Cant pla" $\mathrm{i}$ admès, el 16 de juny següent. ${ }^{236}$

Oleguer BONELLS. Beneficiat. El 5 de juliol de 1756, demanà, l'admissió. Fou examinat "de Cant pla" i admès, el 7 de juliol. L'acta capitular diu que havia cantat "ut moris est" i que el mestre, amb jurament, féu relació de la idoneitat de Bonells. ${ }^{237}$

Francesc de TORRES. Beneficiat. Consta que fou examinat "de Cant pla" i, havent cantat "ut moris est" fou admès, el 8 d'octubre de $1756 .{ }^{238}$

230. SIV. 23, f. 98.

231. SIV. 23 , f. $110 \mathrm{v}$.

232. SIV. 23 , f. $138 \mathrm{v}$.

233. SIV. 23 , f. 149.

234. SIV. 23 , f. $151 \mathrm{v}$.

235. SIV. 22 , f. $113 \mathrm{v}$ i $114 \mathrm{v}$.

236. SIV. 22 ., ff. 145 i $145 \mathrm{v}$.

237. SIV. 22, ff. 148 i 149.

238. SIV. 22 , f. $166 \mathrm{v}$. 
Josep VENDRELL. Prevere i Beneficiat. El 15 d'octubre de 1756, va demanar l'admissió. Fou examinat "de Cant pla" i admès, el 22 del mateix octubre. ${ }^{239}$

Francesc de TORRES. Beneficiat. El 8 d'octubre de 1756, fou examinat "de Cant pla" i, havent cantat "ut moris est", fou admès. ${ }^{240}$

Pau MASDEU. Beneficiat. El 27 de febrer de 1757, va demanar l'admissió. Fou examinat i admès, el 3 de març següent. ${ }^{241}$

Joan RAVANELL. Beneficiat. El 18 d'abril de 1757, va demanar l'admissió. Fou examinat "de Cant pla" $i$ admès, el 2 de maig següent. ${ }^{242}$

Joan Bta. GOLORONS. Doctor i Beneficiat. El 13 de maig de 1757, va demanar l'admissió. Fou examinat $\mathrm{i}$ admès, el 20 del mateix maig. ${ }^{243}$

Marià POU. Canonge Penitencier. L'1 de juny de 1757, va demanar l'admissió. Fou examinat i admès, el 3 del mateix juny. ${ }^{244}$

Adjutori PRAT. Beneficiat. El 20 de juny de 1757, va demanar l'admissió. Fou examinat de cant pla i admès, el 22 del mateix mes i any. ${ }^{245} \mathrm{El} 7$ d'octubre del 1757, el Capítol li concedí presència, per raó dels estudis de filosofia que feia al Col-legi del Sr. Bisbe. ${ }^{246}$

Cosme DOMENECH. Beneficiat. El 12 d'agost de 1757, va demanar l'admissió. Fou examinat "de Cant pla" i admès, el 19 de mateix mes i any. ${ }^{247}$

Francesc CARDONA. Prevere i Beneficiat. El 13 de gener de 1758, va demanar l'admissió. No havent pogut assistir el dia 24 que li havien assignat per a l'examen, fou examinat i admès, el 27 del mateix mes $\mathrm{i}$ any. ${ }^{248}$

Josep ULLDEMOLINS. Beneficiat. El 27 d'octubre de 1758, va demanar l'admissió. Fou examinat i admès, el 9 del mateix mes i any. ${ }^{249}$

Esteve SANPERE. Beneficiat. El 7 de maig de 1759, va demanar l'admissió. Fou examinat "de Cant" i admès, el 9 del mateix mes i any. 250

Miquel ANGLADA. El 22 de juny de 1759, va demanar l'admissió. Fou examinat i admès, el 25 del mateix mes i any. ${ }^{251}$ mes i any. ${ }^{252}$

Rafel GRAÑÓ. L'11 de juliol de 1759, va demanar l'admissió. Fou examinat i admès, el 13 del mateix

Tomàs FEBRÈS. El 14 de desembre de 1759, va demanar l'admissió. Fou examinat i admès, el 17 del mateix mes i any. ${ }^{253}$

Martirià MARTí. El 18 de gener de 1760, va demanar l'admissió. Fou examinat i admès, el 21 del mateix mes i any. ${ }^{254}$

\footnotetext{
239. SIV. 22, ff. 169v. i 170.

240. SIV. 22 , f. $166 \mathrm{v}$.

241. SIV. 23, ff. 9v. i 10.

242. SIV. 23 , ff. 20 i $28 \mathrm{v}$.

243. SIV. 23 , ff. 34 i $35 \mathrm{v}$.

244. SIV. 23 , ff. $41 \mathrm{v}$. i 42 .

245. SIV. 23 , f. $44 \mathrm{v}$.

246. SIV. 23, f. 59.

247. SIV. 23, ff. 53 i 54.

248. SIV. 23 , ff. $70 \mathrm{i} 72 \mathrm{v}$.

249. SIV. 23 , ff. 112 v. i 113

250. SIV.23, ff. 142 i 143.

251. SIV. 23, ff. 142 i 143 .

252. SIV. 23 , ff. 145 v. i 146

253. SIV. 23, ff. 142 i 143.

254. SIV. 23 , ff. 171 i $171 \mathrm{v}$.
} 
Pere ABRIAT. El 23 de maig de 1759, va demanar l'admissió. Fou examinat i "ha estat aprobat i admès", el 28 del mateix mes i any. ${ }^{255}$

Francesc ORTEU. El 31 de maig de 1760, va demanar l'admissió. Fou examinat i admès, el 2 del mes immediatament següent. ${ }^{256}$ mes. ${ }^{257}$

Marià FALCÓ. El 7 de juliol de 1760, va demanar l'admissió. Fou examinat i admès, el 9 del mateix

Francesc BECCAR. El 7 de juliol de 1760, va demanar l'admissió. Fou examinat i admès, el 9 del mateix mes i any. ${ }^{258}$

Ramon LLEDÓ. El 21 de juliol de 1760, va demanar l'admissió. Fou examinat i admès, el 23 del mateix mes i any. ${ }^{259}$

Joan ROSSELL, Dr. El 19 de juliol de 1760, va demanar l'admissió. No consta de l'examen fet. ${ }^{260}$ Probablement pertany a la saga dels músics Rossell que passaren per la Catedral durant el segle XVIII.

Francesc SALT. El 26 de setembre de 1760, va demanar l'admissió. Fou examinat i admès, el 3 del mes immediatament següent. $^{261}$ i any. ${ }^{262}$

Josep UTGÉ. El 3 d'octubre de 1760, va demanar l'admissió. Fou examinat i admès, el 6 del mateix mes

Joan MARIMON, i Manuel Gabriel SOLER. El 26 de juny de 1761, van demanar l'admissió. Foren examinats i admesos, 1 ' 1 del mes immediatament següent. ${ }^{263}$

Anton PONS. El 7 de desembre de 1761, va demanar l'admissió. Fou examinat i admès, l'11 del mateix mes i any. ${ }^{264}$

Josep MARTí. El primer de febrer de 1762, va demanar l'admissió. Fou examinat i admès, el 5 del mateix mes i any. ${ }^{265}$

Anton DESPAU I ESTANY. El 26 d'abril de 1762, va demanar l'admissió. Fou examinat i admès, el 30 del mateix mes i any. ${ }^{266}$

Miquel PINELL. El 30 d'abril de 1762, va demanar l'admissió. Fou examinat i admès, el 7 del mes immediatament següent. ${ }^{267}$

Francesc CELLENT. El 26 de maig de 1762, va demanar l'admissió. Fou examinat i admès, el 28 del mateix mes i any. ${ }^{268}$

Joan GUAL. El 21 de juliol de 1762, va demanar l'admissió. Fou examinat i admès, el 23 del mateix mes i any. ${ }^{269}$

Josep ROVIRA. El 30 de juliol de 1762, va demanar l'admissió. Fou examinat i admès, el 2 del mes immediatament següent. ${ }^{270}$

255. SIV. 23, ff. 189v. i 190.

256. SIV. 23, f.190v.

257. SIV. 23. ff. 195v. i 196v.

258. SIV. 23 , ff. 196 i $196 \mathrm{v}$.

256. SIV. 23, ff. 199 i 199v.

260. SIV. 23, f. 209.

261. SIV. 23, ff. 210 i 211.

262. SIV. 23 , ff. 211 i $211 \mathrm{v}$.

263. SIV. 24, ff. 34 i 35.

264. SIV. 24 , ff. 55 i $55 \mathrm{v}$.

265. SIV. 24, f. $63 \mathrm{v}$.

266. SIV. 24 , ff. 75 i 76.

267. SIV. 24 , ff. 76 i $78 \mathrm{v}$

268. SIV. 24 , ff. 83 i 84.

269. SIV. 24, f. 98.

270. SIV. 24, ff. 99 i 100. 
Marçal ROVIRA. El 20 d'agost de 1762, va demanar l'admissió. Fou examinat i admès, el 23 del mateix mes i any. ${ }^{271}$

Josep CARRERAS I UBACH. El 8 de novembre de 1762, va demanar l'admissió. Fou examinat i admès, el 12 del mateix mes i any. ${ }^{272}$

Jacint CANTARELL. El 26 de novembre de 1762, va demanar l'admissió. Fou examinat i admès, el 29 del mateix mes i any. ${ }^{273}$

Francesc ALÒS. El 10 d'octubre de 1763, va demanar l'admissió. Fou examinat i admès, el 14 del mateix mes i any."Ha cantat lo Ecce sacerdos uti moris est". 274

Joan PARERA. El 31 d'octubre de 1763, va demanar l'admissió. Fou examinat i admès, el 4 del mes immediatament següent. ${ }^{275}$

Pere ENRICH I PUIG. Prevere i Beneficiat. El 31 d'octubre de 1763, va demanar l'admissió. Fou examinat $i$ admès, el 4 del mes immediatament següent. ${ }^{276}$

Sagimon MONTADAS. Beneficiat. El 4 de novembre de 1763, va demanar l'admissió. Fou examinat i admès, el 7 del mateix mes i any. ${ }^{277}$

Sebastià PUIG I MATÓ. Prevere i Beneficiat. El 13 de juliol de 1764, va demanar l'admissió. Fou examinat $\mathrm{i}$ admès, el 20 del mateix mes i any. ${ }^{278}$

Anton GIRÓ. Prevere i Beneficiat. El 17 d'agost de 1764, va demanar l'admissió. Fou examinat i admès, el 20 del mateix mes i any. ${ }^{279}$

Onofre CUTTITA. Beneficiat. El 10 de setembre de 1764, va demanar l'admissió. Fou examinat i admès, el 17 del mateix mes i any. ${ }^{280}$

Sagimon SERRAS. El 16 de novembre de 1764, va demanar l'admissió. Fou examinat i admès, el 19 del mateix mes i any. ${ }^{281}$

Jaume VIÑALS. Prevere i beneficiat. El 8 de juliol de 1765, va demanar l'admissió. Fou examinat i admès, el 12 del mateix mes i any. ${ }^{282}$

Marià PALLIMONJO. Prevere i beneficiat. El 19 de juliol de 1765, va demanar l'admissió. Fou examinat de cant pla $i$ admès, el 24 del mateix mes i any. ${ }^{283}$

Ramon FABRÈS. Beneficiat. El 2 de desembre de 1765, va demanar l'admissió. Fou examinat de cant pla $i$ admès, el 29 del mateix mes $i$ any. ${ }^{284}$

Andreu RASPALL. Beneficiat. El 2 de desembre de 1765, va demanar l'admissió. Fou examinat de cant pla $\mathrm{i}$ admès, el 6 del mateix mes i any. ${ }^{285}$

Roc ESTEVA i MARC. Clergue i beneficiat. El 16 de desembre de 1765, va demanar l'admissió. Fou examinat de cant pla i admès, el 20 del mateix mes i any. ${ }^{286}$

271. SIV. 24, ff. 103v. i 104.

272. SIV. 24 ,ff. $113 \mathrm{v} . \mathrm{i} 114 \mathrm{v}$.

273. SIV. 24 , ff. $117 \mathrm{v}$. i $118 \mathrm{v}$.

274. SIV. 24 , ff. $174 \mathrm{v}$. i $176 \mathrm{v}$.

275. SIV. 24 , ff. 179 i $179 v$.

276. SIV. 24 , ff. 179 i $179 \mathrm{v}$.

277. SIV. 24 , ff. $179 \mathrm{v}$. i $180 \mathrm{v}$.

278. SIV. 24, ff. 211v i 213.

279. SIV. 24 , ff. $216 \mathrm{v}$. i 217

280. SIV. 24, f. $219 v$.

281. SIV. 24 , ff. $227 \mathrm{v}$. i 228

282. SIV. 24, ff. 264v., i 265.

283. SIV. 24 , ff. 267 i $267 \mathrm{v}$.

284. SIV. 24, ff. 284 i 285.

285. SIV. 24, ff. 287 i 288.

286. SIV. 24, ff. 290 i 291. 


\section{Instruments $i$ instrumentistes:}

\section{Orgue}

Orgue de Sta. Eulàlia. El dimecres 23 de juny de 1762, el Sr. canonge Roldós comunicà al Capítol que el co-rector de la parròquia de Sant Francesc de Paula, li havia demanat que els prestessin l'orgue de Santa Eulàlia, per algunes setmanes, ja que, en la susdita parròquia, estaven d'obres i havien desmontat l'orgue, però prometien, que, quan la Catedral l'hauria de menester, els el tornarien. El Capítol concedí el favor sol-licitat. ${ }^{287}$

Orgue. Edicte. El Secretari del Capítol féu present, el dia 29 de maig de 1765, que l'Escolà major, li havia lliurat un edicte, perquè el fixés en el lloc que s'acostumaven de posar aquests documents. L'esmentat edicte era per convocar oposicions al "Magisteri de Orga" de la Vila de Perelada. El document li havia consignat un particular i, a més, no anava signat pels regidors, circumstàncies que feren dubtar a l'esmentat Secretari, si el fixaria o no. El Capítol, però, autoritzà que fos fixat al lloc de costum. ${ }^{288}$

\section{Organistes}

Francesc MARINER. Amb data 16 de gener de 1758, presentà al Capítol una Súplica amb què demanava permís per anar a Girona, ja que havia estat nomenat examinador per a la provisió de la plaça d'organista de la Seu d'aquella Ciutat, tot prometent que deixaria subjecte capàç que el suplís durant la seva absència. El Capítol resolgué donar-li el permís sol-licitat. ${ }^{289}$

El 31 d'agost de 1759, presentà fe de metge per justificar la seva absència per malaltia i demanà la corresponent presència, petició que li fou concedida. ${ }^{290}$

Per l'acta capitular de l'11 de gener de 1765, coneixem l'oferta que el Capítol de Toledo havia fet a Mariner, perquè anés en aquella Catedral, com a segon organista, amb el sou considerable de mil ducats. Mariner, doncs, sol-licità el consell del Capítol, a qui confessà que devia "particulars honras", per decidir-se i perquè mai no se'l titllés de desagraït. El Capítol li respongué que agraïa l'atenció, però que era ell qui havia de decidir, per tractar-se del seu propi interès. ${ }^{291}$

\section{Orgueners}

Josep BOSCÀ/BUSCÀ. Sol-licità la plaça "Mestre de Organs", o d'orguener de la Catedral, per mort del seu germà Anton Buscà, el 22 de març de 1762. El Capítol cometé la petició als Obrers Majors. ${ }^{292}$ Aquests Srs. informaren al Capítol, el dia ú d'abril de 1762, pel que feia a les qualitats dels factors de orgues Anton CASAS $^{293}$ i Josep Buscà i el Capítol resolgué que es procuressin més informació i també de la perícia de Josep Vicenç i que, de moment, es suspengués la provisió de la vacant de Mestre d'orgue. ${ }^{294}$ D'acord amb l'acta capi-

287. SIV. 24 , f. $91 \mathrm{v}$.

288. SIV. 24, f. 257.

289. SIV. 23 , f. 71.

290. SIV. 23, f. 151.

291. SIV. 24 , f. $233 \mathrm{v}$.

292. SIV. 24, f. 70.

293. SIV. 24 , f. 71 v.: L'acta capitular delo dia 29 de març de 1762, diu que Anton Casas "Mestre de Orgas de la Villa de Reus" i el seu fill, manifestaren al Capítol de la Catedral de Barcelona, que volien establir-se en aquesta Ciutat i demanaven ésser nomenats factors d'orgues de l'esmentada Catedral.

294. SIV. 24, f. 72 v. 
tular del mateix ú d'abril, consta que la mare de l'esmentat Josep Vicenç BUSCÀ, intercedí a favor de la nomenació del seu fill, ja que el seu marit difunt, Anton Buscà, factor d'orgues, havia tingut cura tants d'anys de l'orgue de la Catedral i n'havia tramès tota la seva perícia al seu fill. ${ }^{295} \mathrm{El}$ propi Josep Vicenç presentà també, per sa part, una súplica i diferents certificats d'orgues que havia "ordenat", a fi que el Capítol jutgés millor, pel que feia a la seva habilitat i suplicava el nominessin orguener, com també ho feia la seva mare. El Capítol ho cometé als comissionats, Sr. Sentmenat i Sr. Joven. ${ }^{296}$ Aquests Srs., el dia 14 de maig de l'any corrent, feren relació al Capítol dels pretendents, detallant les circumstàncies de cadascun i conclogueren que es podia passar a la votació, tenint en compte, a més, la necessitat que hi havia d'afinar l'orgue. Es resolgué proveir-lo en el capítol següent. ${ }^{297}$ En el capítol del 21 immediatament següent, el canonge Nadal manifestà el seus dubtes, pel que feia a la convocatòria per a cobrir la vacant de l'orgue, en el sentit que s'estava tractant i el Capítol resolgué que s'hi convidés. ${ }^{298}$ El 24 del mateix, el Capítol votà per escrutini la provisió de l'ofici de Factor de Orgas" i resultà elegit per pluralitat de vots, Josep Buscà. ${ }^{299}$

\section{Manxaires}

Feliu ROS. El 26 de febrer de 1761, presentà una Súplica al Capítol, demanant que, aquest, posés fi a les diferències que hi havia entre ell i el Mestre de Capella, fent que aquest li pagués "lo real deu percibir en Sta. Eularia per las Completas i Oficis de Octava". La súplica fou comesa al Sr. President, perquè esbrinés si els altres músics havien cobrat, en el qual cas , es pagués també al susdit Ros. ${ }^{300}$

\section{Arpa}

Francesc RUEDA i Joan ROSSELL. "Havent passat â major vida" l'arpista mn. Joan Rossell, Fc. Rueda presentà una súplica al Capítol, el 10 d'octubre de 1763, tot demanant el nomenament per a arpista primer. Adduïa els més de setze anys que servia com arpista segon i que també tocava la trompa i el clarí, a la Capella de Música de la Catedral. Pel que feia al salari, manifestà que s'acontentava amb el "q.e sia del agrado, i satisfaccio de V. S.". El Capítol, certament, l'anomenà arpista primer, amb el salari de 20 lliures anuals. ${ }^{301}$

Joan ROSSELL/ROCELL. Apareixen simultàniament, a la Catedral, dos Joan Rossell, l'un l'arpista, l'òbit del qual degué ocórrer el 5 d'octubre de 1763, i la sepultura el dia següent, com es llegeix al corresponent Llibre d'Òbits. ${ }^{302} \mathrm{El}$ document que tot seguit comentaré fa pensar en un Joan Rossell, el qual no se'l relaciona amb la música i no s'ha de confondre amb l'esmentat Joan Rossell arpista, el qual havia finit la data susdita. Abans, doncs, del 15 d'octubre de 1763, data de la sessió capitular que m'ocupa. En ella es llegeix, efectivament, que el beneficiat Joan Rossell estava tan greu, que el propi Capítol decidí viaticar-lo, per consell de metge, encara que, després, no consta de la seva defunció. ${ }^{303}$ Probablement es tracta del Dr. Joan Rossell que demanà l'examen de cant, el 19 de juliol de 1760, del qual n'he parlat més amunt.

\section{Arxillaüt}

Pretendents a l'arxillaüt. El 26 d'agost de 1757, el Sr. Ibarra comunicà al Capítol el nom de tres pretendents a ocupar la plaça d'arxillaüt, els quals eren: Sebastiá VIDÁL, Vicens ROSSELL i Josep RUAIX/

295. SIV. 24 , f. 72.

296. SIV. 24, f. 78

297. SIV. 24 , f. $80 \mathrm{v}$.

298. SIV. 24, f. 82.

299. SIV. 24 , f. 83.

300. SIV. 24, f. $8 \mathrm{v}$.

301. SIV. 24 , f. $174 \mathrm{v}$

302. Llibre d'Òbits, 1734-1765, f. 297: "8bre de 1763. Rossell. A 6 Sep[ultur]. a de Cap[íto].1 Comp[le].ta del cos del R.t Joan Rossell p.re y Arpista de la present Igl. ${ }^{\text {a }}$ :

303. SIV. 24, f. 177. 
ROAIX. Però també digué, que li semblava més convenient posar un organet o una espineta que no pas l'arxillaüt. El Capítol resolgué que no s'hi innovés res, quan a l'instrument. ${ }^{304}$

El dilluns 12 de setembre de 1757, el mateix Sr. Albert Ibarra féu relació dels pretendents a la plaça d'arxillaüt, encara que, aquesta vegada, sense donar els noms. El Capítol decidí ajornar-ho fins que al susdit Sr. Ibarra li semblés oportú fer-ne relació un altre cop. ${ }^{305}$

El document que ara m'ocupa és molt interessant, perquè a més de donar el nom dels pretendents a l'arxillaüt i dir qui en fou el dessignat, expressa també el lloc on treballava cadascú d'ells -al present n'eren quatre en lloc de tres-i la raó per la qual l'un fou nomenat i els altres rebutjats. Es tracta de l'acta capitular del 16 de gener de 1758, on es diu que Josep Roaix era l'arxillaütista del Pi, el qual "si be sap mes de una mediania, era molt curt de vista"; Joan OLIVERÓ, era l'arxillaütista de Santa Maria, "pero â mes de tenir edát, está impedít, y no es facil se contentia ab lo primer salari de dit Instrument”; Vicenç Rossell era músic del Palau, pero "es Home de edát, y ha molts Anys, q.e no ha exercitat tocar lo Arxillaút"; i, finalment, Sebastià Vidal, "si be no té, sinó 17 Anys, / acompaña molt be ab lo Arxillaút â satisfacció del M.e de Cape-/lla" i, d'ençà del Dimecres Sant, acompanyava a totes les funcions amb l'arxillaüt, i a més, semblava que s'acontentaria amb la mitja part de la Capella. El Capítol nomenà aquest darrer, amb la mitja part de la Capella ${ }^{306}$ No obstant aquesta resolució de la mitja part de la Capella, el 2 d'abril del 1759, a petició del propi Sebastià i del seu pare, la hi donaren tota sencera, tenint en compte que era un "minyó" d'esperances, no tenia cap altre lucre i el transport de l'instrument li suposava grans despeses. ${ }^{307}$

Encara trobem Sebastià Vidal, clergue, demanant augment de salari, per ser-li insuficient el que rebia, per a les despeses de cordes i transport de l'instrument -acta capitular del 9 de gener de 1761- (súplica comesa als Ö̈dors de Comptes); o que li donessin el que s'acostumava a donar als seus predecessors, per ser escàs el que rebia per a la seva manutenció, després de cinc anys de servei -acta cap. del 7 de setembre del susdit 1761(súplica comesa al Sr. Protector de la Capella). Finalment, el 25 dels mateixos mes de setembre i any 1761, féu relació del Memorial de Sebastià Vidal que li fou comès i el Capítol resolgué que la Súplica no tenia lloc. ${ }^{308}$ Tanmateix, amb altra Súplica del 10 d'octubre de 1763, li concediren un salari anual de 20 lliures. ${ }^{309}$

Manuel PLANES/PLANAS. De l'anàlisi dels documents referents a "Manuel Planas", resulta evident que foren dos els músics d'aquest nom i cognom, l'un era el pare i l'altre el fill, del qual ja n'he parlat a l'apartat dels Escolans de cota de grana. Els corresponents al pare, aporten les dades següents:

L'acta capitular del 29 de juliol de 1757 diu que Manuel Planas, contralt i arxillaüt segon de la Capella, demanà la plaça vacant d'arxillaüt primer, "per la falta, q.e temps ha se repara de Fran.co Rossell" i per a la qual es considerava capàç. En aquest cas, renunciaria a la de contralt, ja que el metge li havia consellat que, si s'estimava la salut, havia de deixar de cantar. La súplica fou comesa al Sr. Protector de la Capella. ${ }^{310}$

El Capítol atengué aquesta petició de Planas i el dia primer del següent mes d'agost, el Sr. Ibarra manifestà al Capítol que se n'havia informat del cas i que era veritat tot el que manifestava l'interessat i que, si deixava l'ofici de contralt, igualment l'hauria d'assistir el Capítol. D'altra banda, era una persona constant, hàbil en l'arxillaüt i el propi Capítol ja l'havia admès com arxillaüt segon. El Capítol resolgué concedir-li la plaça vacant d'arxillaüt. ${ }^{311}$ Els esdeveniments, lamentablement, demostraren que la salut de Planas era, fins i tot, molt més greu del que es pensava. Efectivament, uns dies després, el 12 del mateix agost, la seva vídua, presentava al Capítol la situació lamentable, en què es trobava, després de morir el seu marit i demanava tot

304. SIV. 23 , f. $54 \mathrm{v}$

305. SIV. 23, f. 56.

306. SIV. 23 , f. 71 .

307. SIV. 23, f. 134.

308. SIV. 24 , ff. $1 \mathrm{v}, 45$ i $46 \mathrm{v}$.

309. SIV. 24, f. $174 \mathrm{v}$.

310. SIV. 23, f. $50 \mathrm{v}$.

311. SIV. 23, f. $51 \mathrm{v}$. 
el socors que el Capítol li pogués oferir. La dona es trobava en cinta i havia d'alimentar dos infants, al temps que havia de pagar l'enterrament del seu marit i de dues criatures. El Capítol li féu la gràcia dels enterraments. ${ }^{312}$

\section{Obò̀}

Benet PUIGDENGOLA. Oboè segon del Palau. Sabedor de la imminent partença del segon oboè de la Catedral, demanà per a ell, el 25 d'agost de 1758, el corresponent nomenament per cobrir la vacant, quan es produís. Petició que fou comesa al Sr. Protector de la Capella. ${ }^{313}$

Francesc JANER. El 10 de novembre de 1758, demanà ser admès a la Capella, en l'ofici d'oboè, flauta i baixó, petició que fou comesa al Protector de la Capella. ${ }^{314}$

Oboè. Pretendents. El 13 de novembre de 1758, el Sr. Joan d'Alòs, presentà al Capítol els Memorials dels pretendents a la plaça d'oboè, la qual es suposava que vacaria, però que en realitat no vacava encara, ni es preveia quan vacaria, perquè en disposés. Es resolgué que no se'n tractés d'aquesta qüestió, fins a tant no es produís la vacant. ${ }^{315}$

Joan CLIMENT. L'acta del 8 d'octubre de 1764, aporta una bona llista de mèrits d'aquest pretenent a la plaça de primer oboè de la Capella de la Catedral. Es diu que a més de l'oboè, també tocava la flauta i el baixò; que havia servit any i mig la Capella d'aquesta Seu; que havia tocat tres anys al Teatre de la present Ciutat de Barcelona; que havia servit d'escolà, a la Catedral de Girona i que, aleshores, servia la Capella del Palau. La seva Súplica fou comesa al Sr. Protector de la Capella. ${ }^{316}$

Manuel PLANAS. Es tracta del fill. Per l'acta del 12 d'octubre de 1764, consta que es cobriren la plaça de primer oboè i la de segon. Fc. Fontrodona que n'era el segon passà a primer i Manuel Planas, fill, ocupà la de segon, la qual deixava Fontrodona. ${ }^{317}$

Francesc FONTRODONA. El 8 d'octubre de 1764, demanà per a ell el nomenament de primer oboè, plaça vacant per mort de Joan Ciurach, atenent als catorze anys que servia l'ofici d'oboè segon. La súplica, com de costum, fou comesa al Sr. Protector de la Capella. ${ }^{318}$

Agustí SANS. Professor de música. També fou altre dels pretendents a la plaça de primer oboè, d'acord amb l'acta capitular de 8 d'octubre de 1764. La seva súplica també fou comesa al Sr. Protector de la Cape1la. ${ }^{319}$

\section{Clarins}

Clarins. Fer-ne. El 13 de juliol de 1761, el canonge Vinyes exposà que s'havien de fer clarins i que els músics havien proposat que en pagués un el Capítol i altre el qui en tenia cura. Com sempre, es cometé al Sr. protector de la Capella. ${ }^{320}$ I dos dies després, això és, el 13 de juliol, el mateix Sr. Vinyes es queixava que els músics el molestaven massa, en qüestió dels clarins i demanà al Capítol que es prengués alguna resolució que l'exonerés d'aitals molèsties. El Capítol resolgué ajornar la qüestió, fins a tant no es restituís a l'església el canonge Orteu, Protector dels Escolans. ${ }^{321}$

312. SIV. 23, f. 53 .

313. SIV. 23, f. $107 \mathrm{v}$.

314. SIV. 23, f. 113.

315. SIV. 23, f. $113 \mathrm{v}$

316. SIV. 24 , f. $222 \mathrm{v}$.

317. SIV. 24 , f. $223 \mathrm{v}$

318. SIV. 24, f. 222v.

319. SIV. 24 , f. $222 \mathrm{v}$.

320. SIV. 24 , f. $37 \mathrm{v}$.

321. SIV. 24, f. 38. 


\section{Trompes / Trompes de caça}

Josep DRUMENT. Trompa. L'acta capitular del 13 d'agost de 1759, al-ludeix a la seva malaltia que devia ser llarga i el seu suplent, Francesc Rueda, demanava salari, al temps que recordava que se li devien uns ròssecs. El Capítol ho deixà a mans del Sr. Protector de la Capella. ${ }^{322}$

Miquel RIBAS. El Capítol concedí 20 lliures de salari a Miquel Ribas, músic, el 9 d'abril del 1764, en atenció als deu anys que servia la Catedral, amb els instruments de contrabaix i trompa i, segons el propi Ribas, amb el detall que, mentre el Capítol proveïa els instruments, en el seu cas havia estat ell qui se n'havia proveït de nous, havent-se deteriorat els de la Catedral. ${ }^{323}$

En canvi, a la petició que féu, el 26 de novembre del mateix any 1764, en el sentit de poder assistir a altres conveniències, dins de Ciutat i sense faltar al servei de la Catedral, el Capítol manà al Protector de la Capella que ho estudiés. ${ }^{324}$ El Sr. Joan Alòs, això és, el susdit Protector de la Capella, manifestà el seu parer al Capítol, el 3 de desembre del mateix any, en el sentit que, si ho concedia a Ribas, molt probablement tots els altres músics també ho demanarien i podria ser en detriment de la Catedral i, per això, el Capítol resolgué que no tenia lloc la petició. ${ }^{325}$

\section{Viola}

Josep SOLER. Músic de segona viola. El 8 de febrer de 1762, demanà un certificat del temps que havia servit la Capella i el Capítol resolgué que li fos lliurat. ${ }^{326}$ Dos anys després, el 7 de setembre de 1764, comunicà al Capítol l'oferta perpètua que li feien del Palau, de 350 lliures i demanava "q.e V. S. deliberia, lo q.e sia de son gust". El Capítol li respongué que es donava per ben servit i que podia admetre la conveniència. ${ }^{327} \mathrm{El} 17$ de setembre de 1764, el Sr. Alòs exposà que tenia notícies que el Mestre de Capella volia acomiadar Josep Soler, el qual tenia permís per acceptar l'oferta del Palau. El Capítol resolgué que digués al Mestre que l'acomiadament corresponia al Capítol, i li manà que l'admetés a les festes i als altres actes, mentre no tingués l'admissió i la perpetuació del Palau, en les condicions que s'havien expressat. ${ }^{328}$

\section{Violí}

Falta de violins. El 15 de setembre de 1758, el Mestre de Capella féu present al Capítol la manca de "Subjectes per lo Violi", raó per la qual no podia desenvolupar-se degudament a les funcions i suplicava que s'hi posés remei. ${ }^{329}$

Isidre PALLÉS. El 23 de febrer de 1756, presentà una Súplica al Capítol, amb què demanava ésser admès a la mitja part de la Capella, tot fent constar que havia servit set anys com a escolà i tres com a violinista i també que era pobre i assistia la seva mare i dues germanes. La Súplica fou comesa al Protector dels Escolans. ${ }^{330}$ Aquesta mateixa súplica la presentà el 21 de maig següent i també fou comesa al Sr. Protector. ${ }^{331}$ Encara ho va demanar una tercera vegada, el 2 de juny del mateix any, però el Sr. Antonino Sentmenat, com a Protector, informà que aleshores no hi havia cap vacant, a la Capella $\mathrm{i}$, en conseqüència, el Capítol respongué a Pallés que, en aquells moments, no tenia lloc la Súplica. ${ }^{332}$

322. SIV. 23, f. 149.

323. SIV. 24 , f. $198 \mathrm{v}$.

324. SIV. 24, f. 229.

325. SIV. 24, f. 230.

326. SIV. 24, f. 64.

327. SIV. 24, f. 219.

328. SIV. 24, f. 220.

329. SIV. 23 , f. $109 \mathrm{v}$.

330. RES. Cap. 22, f. 121.

331. SIV. 22, f.139.

332. SIV. 22 , f. $141 \mathrm{v}$. 
Fou el 3 de desembre de l'any 1762 que, el Sr. Fc. Orteu, féu relació del Memorial dels dos músics que demanaven el salari que tenia el quondam Lluís Martí, això és, el de l'Isidre Pallés, al qual considerava més acreedor i el d'un tal "Aloy" que demanava la part de la Capella. Però opinà que la Capella es carregava "d'Individuos, y de parts...", ja que, en poc temps, n'havien entrat dos a fruir de la part de la Capella i li semblava que la petició de l'“Aloy" no tenia lloc, opinió que féu seva el Capítol i li digueren que, al seu degut temps, es tindria present. ${ }^{333}$

Carles TEIXIDÓ / TEIXIDOR. D'antuvi, fa pensar en la saga dels músics Teixidor del segle XVIII i començament del segle XIX, però, de moment, no es tenen indicis per afirmar, ni negar un possible parentiu. Havia estat escolà de cota de grana i en parlo en una altra publicació. ${ }^{334}$ Es tracta d'un violinista segon que portava vint $i$ sis anys de servei a la Catedral, segons l'acta capitular del 12 de juliol de 1758, dels quals vint i sis anys, els quatre darrers cobrava un salari de 10 lliures, però no li abastaven, ja que tenia cura del seu pare vell i, per això, demanava un augment de salari. La Súplica fou comesa al Sr. Protector de la Capella. ${ }^{335}$ El 17 dels mateixos mes i any, el Sr. Alòs digué al Capítol que era veritat tot el que exposava Teixidor, però el Capítol resolgué que no tenia lloc. ${ }^{336} \mathrm{El} 5$ d'octubre de 1761, tornà a demanar l'augment de salari i la Súplica anà altre cop al Protector de la Capella ${ }^{337}$, el qual, però, quatre dies després, informà novament al Capítol, de la Súplica de Teixidor i el Capítol li augmentà el salari de 10 a 25 lliures.

Lluís PULLER. El 15 de setembre de 1758, es llegí en capítol una Súplica del Mestre de Capella, amb què demanava alguna providència sobre la manca de violins a la Capella, Súplica que es passà al Sr. Protector i el 25 del mateix mes i any, el Sr. Joven, en absència del Protector Alòs, informà sobre aqueix Memorial del Mestre. En conseqüència, Puller fou nomenat violinista i se li donà part en la Capella. ${ }^{338}$

Pere ROS. Clergue i músic. El 29 de març de 1759, recordà al Capítol que havia estat promogut a SubDiaconal mn. Gabriel Terri. Suposant, doncs, que restava vacant la plaça de violí que aquell obtenia, demanava, en consequèència, que la hi adjudiquessin a ell. La Súplica fou comesa al Protector de la Capella de Música. ${ }^{339}$ Un mes després, aproximadament, això és, el 27 d'abril, el Sr. Alòs informà sobre aquesta Súplica i el Capítol resolgué que no hi havia $1 l o c$, puix que no hi havia cap plaça de violí vacant ${ }^{340}$ Podria ser germà, o parent del Feliu Ros, estudiat més amunt.

Uns anys després, el 26 d'abril de 1762, Ros presentà altra Súplica, demanant part en la Capella, la qual servia des de feia quatre anys. La Súplica fou comesa, com era norma en aquests casos referents a la Capella de Músicà, al Sr. Protector de la mateixa. ${ }^{341}$ En fou admès, el 30 del mateix abril, malgrat que es dubtà, tot i constar del mèrit del suplicant. ${ }^{342}$

El 26 de novembre de 1762, Ros suplicà al Capítol que li concedís el salari que fruïa el difunt Lluís Martí, al qual substituïa des de feia cinc anys, Súplica que fou comesa al Sr. Protector de la Capella. ${ }^{343}$

Jaume ROSQUELAS / ROSQUELLAS. Músic de violí. El 30 de juliol de 1762, Rosquelas (sic) va manifestar al Capítol que feia uns set anys que servia la Capella i en les absències de mn. Capó, el suplia com a primer violí i, no tenint cap salari i necessitant-lo per mantenir-se, demanava que li donessin el que podia correspondre al suplicant. La súplica fou comesa al Sr. Protector. ${ }^{344} \mathrm{~L}$ 'aval, signat pel canonge Tagell, Protec-

333. SIV. 24, f. 119v.

334. Pavia i Simó, Josep, Tonos de francesc Valls (c. 1671-1747), vol. II, CSIC, Barcelona, 2001, pg. 58.

335. SIV. 23, f. 100.

336. SIV. 23, f. 101v. i SIV. 24 , f. 48.

337. SIV. $24, \mathrm{f}, 47 \mathrm{v}$.

338. SIV. 23, ff. 109v. i 110v.

339. SIV. 23, f. $132 \mathrm{v}$.

340. SIV. 23, f. 135.

341. SIV. 24 , f. 75.

342. SIV. 24, f. 117v.

343. SIV. 24 , f. $76 \mathrm{v}$.

344. SIV. 24, f. 99. 
tor de la Capella, l'1 d'agost immediatament següent, fou presentat al Capítol, el 9 d'aquest mateix mes. El contingut era del tenor següent: que de l'informe del Mestre de Capella i altres músics, resultava ser veritat el que s'hi deia i considerava a Rosquellas (sic) mereixedor de la gràcia que demanava, per a major utilitat i llustre de la Capella. I li concediren 20 lliures anuals, per via de salari. ${ }^{345}$

\section{Violó}

Violó gran / Contrabaix / Violó gros i també contrabaix de Viola. El 5 de juliol de 1758, el Mestre Josep Pujol manifestà al Capítol que el violó gran, propietat del Capítol, s'havia espatllat i que, si semblava bé, es podria fer reparar. Es cometé la Súplica al Sr. Protector. ${ }^{346}$ Aquest Sr. que l'era el canonge Alòs, informà al Capítol, dos dies després, que el pressupost que li havien fet pujava fins a " 24 p.s (=peces) de 8 antiguas". El Capítol deixà la solució a les seves mans ${ }^{347} \mathrm{El} 22$ de setembre següent, ja estava reparat i el Sr. Joven, en absència del Sr. Alòs, digué que, tal com s'acordà el 8 de maig (data errònia, pel que s'acaba de dir, ja que fou el 7 de juliol), el mestre que l'havia reparat, demanava les 24 peces. Es resolgué que es fes manament. ${ }^{348}$

Francesc CASAMOR. El Sr. Sentmenat, com a Protector de la Capella, informà al Capítol, el 7 de juliol de 1756, que Casamor s'havia absentat urgentment, durant uns dies, per malaltia molt greu de la seva mare i que només havia tingut temps d'avisar al Mestre de Capella, el qual no ho comunicà. Els músics, doncs, desconeixedors, exigien el repartiment de la part corresponent al susdit Casamor, però ell, el Protector, digué que primer ho consultaria amb el Capítol. Aquest resolgué que es donessin les 7 lliures, 10 sous i 1 diner a Casamor, donà les gràcies al Protector per la prudència haguda i li recomanà que de la mateixa manera procurés apaivagar els ànims i que donés una bona reprensió als tres, o quatre que movien bregues. ${ }^{349}$

El 8 de juny de 1759, presentà una súplica amb què demanava el salari de contrabaix que tenia el seu predecessor i fou comesa al Protector de la Capella de Música ${ }^{350}$ El 25 del mateix mes i any, atenent a una nova súplica de Casamor, el nomenaren oficial i li assignaren 25 lliures de salari. ${ }^{351}$ 